\title{
Diversity of arborescent lineages of Crotoneae (Euphorbiaceae) in the Brazilian Atlantic Rain Forest
}

\author{
Rafaela F. dos Santos $^{1} \cdot$ Ricarda Riina ${ }^{2}\left(\mathbb{D} \cdot\right.$ Maria B. Rossi Caruzo ${ }^{1,3}$
}

Received: 10 March 2017 / Accepted: 28 June 2017 / Published online: 19 August 2017

(C) Springer-Verlag GmbH Austria 2017

\begin{abstract}
We conducted fieldwork and herbarium research to investigate the morphological diversity, taxonomy, and geographic distribution of arborescent lineages of tribe Crotoneae (Euphorbiaceae) in the Brazilian Atlantic Rain Forest domain, a neotropical region considered one of the world's hot spots of biodiversity. We found that arborescent lineages of Crotoneae are represented in the Atlantic Rain Forest by two genera (Croton and Brasiliocroton) and 23 species. Of this total, $70 \%$ of the species are endemic to the Atlantic Rain Forest. The genus Brasiliocroton, which is endemic to Brazil, includes two species, and Croton is represented by 21 species. We provide identification keys, update morphological description of key characters, include pertinent taxonomic comments, and illustrate most of the studied species with live photographs to facilitate taxonomic identification. The conservation status of each species is also evaluated. We establish five new synonyms, one superfluous name, and nine lectotypifications.
\end{abstract}

Handling editor: Mike Thiv.

Electronic supplementary material The online version of this article (doi:10.1007/s00606-017-1441-8) contains supplementary material, which is available to authorized users.

Ricarda Riina

rriina@rjb.csic.es

1 Campus Diadema, Departamento de Ecologia e Biologia Evolutiva, Universidade Federal de São Paulo, Diadema, SP CEP 09972-270, Brazil

2 Real Jardín Botánico, RJB-CSIC, Plaza de Murillo 2, 28014 Madrid, Spain

3 Instituto de Botânica, Secretaria do Meio Ambiente, Cx. Postal 3005, São Paulo, SP CEP 01061-970, Brazil
Keywords Brasiliocroton - Croton - Conservation · Endemism $\cdot$ Flora of Brazil $\cdot$ Neotropics

\section{Introduction}

The tribe Crotoneae Dumort. was recently redefined by Berry et al. (2005a) based on phylogenetic studies. According to their results, the circumscription of the tribe includes seven genera (Acidocroton Griseb., Ophellantha Standl., Sagotia Baill., Sandwithia Lanj., Brasiliocroton P.E.Berry \& Cordeiro, Astraea Klotzsch and Croton L.), among which Croton stands out as one of the largest Angiosperm genera (Frodin 2004; Govaerts et al. 2000; van Ee et al. 2011) with 1200 species distributed in tropics and subtropics worldwide. In comparison, the other six genera in the tribe are relatively poor in species, ranging from two to about 15 species, and are all restricted to the Neotropics.

There is no known morphological synapomorphy that diagnoses the Crotoneae clade, so the tribe is mostly defined by molecular characters (Berry et al. 2005a; Wurdack et al. 2005) and its geographic range, with all its lineages likely originating in the Neotropics according to the current phylogenetic hypothesis, and only Croton reaching further to the Old World (Berry et al. 2005a; van Ee et al. 2011).

A recent account of Euphorbiaceae for the Brazilian Flora (Flora do Brasil 2020 in construction) recognized three genera (Astraea, Brasiliocroton, and Croton) and 61 species of tribe Crotoneae for the Atlantic Rain Forest (ARF) domain. Astraea is a genus with about 13 species of subshrubs and shrubs, occurring in open vegetation or forest edges in South America and mainly in Brazil (Caruzo et al. 2014). Brasiliocroton includes only two arborescent species, both endemic to Brazil (Berry et al. 2005b; Riina 
et al. 2014). Finally, Croton, the second largest genus of Euphorbiaceae, is also the most diverse genus of that family in the Brazilian flora (BFG 2015). Research on Brazilian Euphorbiaceae has been very active recently thanks to the Flora of Brazil initiative and other regional floristic projects (e.g., Caruzo and Cordeiro 2007; Secco et al. 2012a, b; Santos and Caruzo 2015; Silva et al. 2014a; Crepaldi et al. 2016; Medeiros et al. 2016; Viana et al. 2016), and recognition of new Euphorbiaceae species continues, with around 70 new species occurring in Brazil having been described in the last decade (e.g., Caruzo et al. 2008, 2010, 2016; Cordeiro et al. 2008; Lima and Pirani 2008; Secco 2009; Secco and Berry 2010; Carneiro-Torres et al. 2011; Secco et al. 2012a, b; Silva et al. 2014b).

The shrubby habit is the most common growth form found in tribe Crotoneae, and it has apparently evolved independently in Croton multiple times (Arevalo et al. 2017). However, in the case of the Brazilian Amazonian and ARF domains, tree species are significant components of the total diversity of Crotoneae in these domains (Fig. 1). This is not surprising, as different forest formations cover most of the extension of these phytogeographic regions. Given the importance of trees in the ARF and the need to provide updated species treatments for the ongoing Flora of Brazil project (Flora do Brasil 2020 in construction), we set to update our knowledge about the diversity and distribution of arborescent species of tribe Crotoneae in that domain. We aimed to detect new records of species occurrence, establish new synonyms and provide lectotypifications when necessary. We built keys, comparative tables for distinguishing similar species, and illustrated most species using field photographs to facilitate taxonomic identification. Pertinent comments on species with problematic taxonomy are also provided. Finally, we updated taxon geographic ranges and evaluated the conservation status of each species.

\section{Materials and methods}

In the context of this work, a tree is defined as a woody plant $5 \mathrm{~m}$ tall or higher, with a single trunk (DBH $>10 \mathrm{~cm}$ ) up to the base of its crown (Font Quer 1977). The definition of Atlantic Rain Forest (ARF) used in this study is that of Oliveira-Filho and Fontes (2000), which encompasses all different forest physiognomies that occur from the east of the dry corridor from northeastern to southern Brazil (states of Alagoas, Bahia, Ceará, Espírito Santo, Goiás, Mato Grosso do Sul, Minas Gerais, Paraíba, Paraná, Pernambuco, Piauí, Rio de Janeiro, Rio Grande do Norte, Rio Grande do Sul, Santa Catarina, São Paulo and Sergipe), east Paraguay and northeastern Argentina, including the "brejos nordestinos" and "Araucaria Forest" (Fig. 2).

Our data come from field observations and analysis of about 2000 collections (Online Resource 1) deposited in the following herbaria: ALCB, ASE, BHCB, CEPEC, CVRD, ESA, HUEFS, HUEM, HUPG, HESC, IPA, MAC, MBM, MBML, PEUFR, R, RB, SJRP, SP, SPF, SPSF, UEC, UFP, VIES (abbreviations according to Thiers 2016). Type specimens were analyzed through images available at the JSTOR Global Plants website (http://plants.jstor. org/). Data from additional specimens photographs taken in several herbaria outside of Brazil (A, BR, C, DAV, F, G, G-DC, GH, K, MA, MO, MPU, NY, P, R, S, US, W, WIS, WU) were also taken into account.

For each taxon, we include a brief morphological description using characters that give the overall aspect of the plant as well as useful diagnostic characters. Most morphological terms used in descriptions follow Hickey (1973), Radford et al. (1974), Vitarelli et al. (2015), and Webster et al. (1996). Trichome terminology follows Webster et al. (1996) with some modification according to recent morpho-anatomical studies in Crotoneae (Feio et al. 2016; Vitarelli et al. 2016). Useful characters
Fig. 1 Distribution of different growth forms of tribe Crotoneae across Brazilian biogeographic domains. Data from the Flora do Brasil (2020, in construction) with updates and modifications from our own records

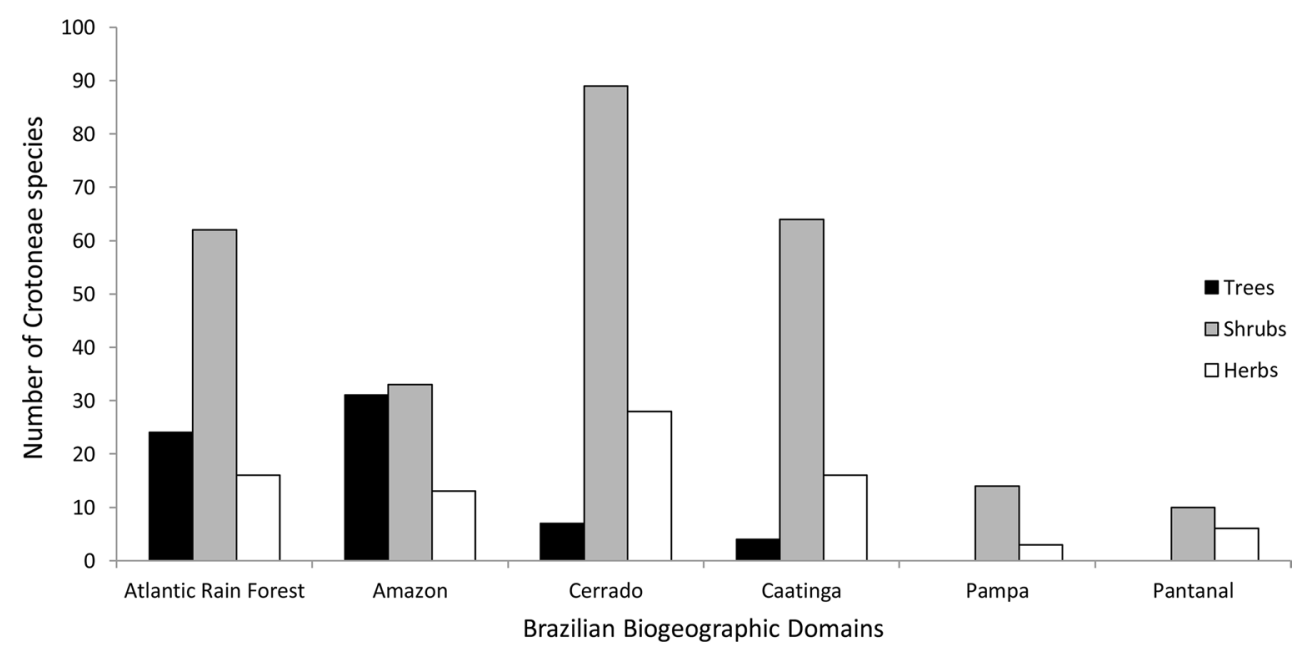


Fig. 2 Area of the Atlantic Rain Forest Domain (gray shaded area) according to the definition of Oliveira-Filho and Fontes (2000), see text. Country boundaries are shown in continuos lines and Brazilian states in dashed lines. Source WWF database (Olson et al. 2001)

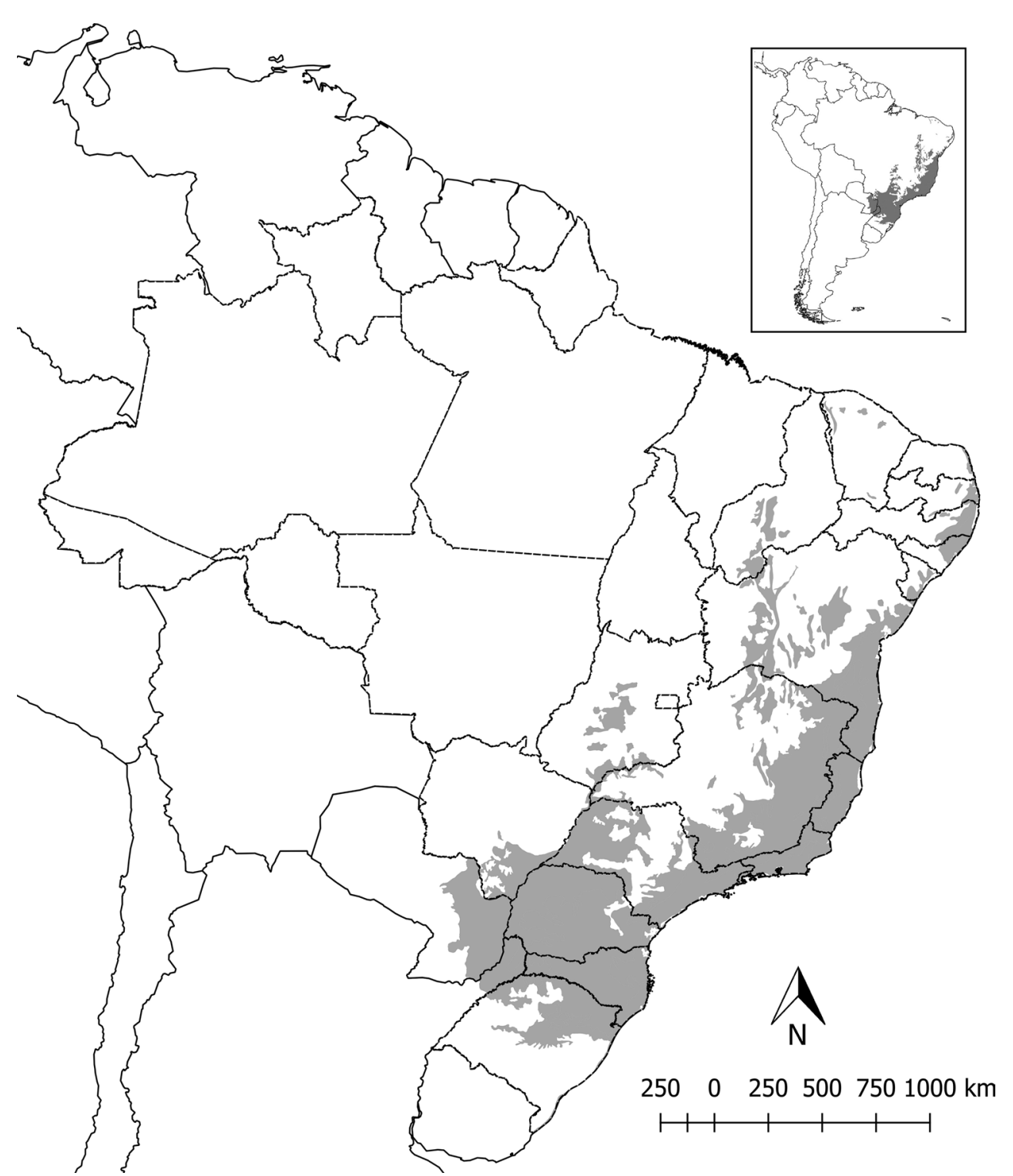

distinguishing similar species or frequently confused ones are provided in tables.

Under each accepted name, only new synonyms are listed. The establishment of new synonyms was based on the analysis of original descriptions, type collections, and direct observations of populations in or near type localities. Phenology information was sourced from the available herbarium specimens. The assessment of conservation status was carried out according to the IUCN Red List Categories and Criteria (2012).

\section{Results and discussion}

The ARF presents 23 arborescent species of tribe Crotoneae, which belong to two genera: Brasiliocroton, with two species (B. mamoninha and B. muricatus), and Croton, with 21 species distributed among seven different Croton sections (Table 1) according to the current infrageneric classification of the genus (van Ee et al. 2011). The richest sections in the ARF are sect. Cyclostigma (9 spp.) and sect. Cleodora (5 spp.), whereas the small sect. Prisci and sect. Quadrilobi are endemic to this domain. Croton oliganthus, a rare and poorly known taxon, is the only tree species of Croton occurring in the ARF that was listed among the unplaced taxa in the van Ee et al. (2011) classification scheme. Here we propose its tentative placement, based on morphological data, in Croton sect. Quadrilobi (see discussion under $C$. oliganthus in the taxonomic treatment). Below we present a detailed account of each species and further discuss individual cases with problematic taxonomy. The genus description of Brasiliocroton has not 
Table 1 Arborescent species of Croton from Atlantic Rain Forest and their sectional position according to van Ee et al. (2011)

\begin{tabular}{|c|c|}
\hline Species & Section \\
\hline C. gracilipes Baill. & Sect. Adenophylli Griseb. \\
\hline C. campanulatus Caruzo \& Cordeiro & Sect. Cleodora (Klotzsch) Baill. \\
\hline C. hemiargyreus Müll.Arg. & Sect. Cleodora \\
\hline C. organensis Baill. & Sect. Cleodora \\
\hline C. rottlerifolius Baill. & Sect. Cleodora \\
\hline C. salutaris Casar. & Sect. Cleodora \\
\hline C. alchorneicarpus Croizat & Sect. Cyclostigma Griseb. \\
\hline C. celtidifolius Baill. & Sect. Cyclostigma \\
\hline C. echinocarpus Müll.Arg. & Sect. Cyclostigma \\
\hline C. macrobothrys subsp. macrobothrys Baill. & Sect. Cyclostigma \\
\hline C. macrobothrys subsp. septentrionalis Caruzo \& R.F.Santos & Sect. Cyclostigma \\
\hline C. medusae Müll.Arg. & Sect. Cyclostigma \\
\hline C. pseudopopulus Müll.Arg. & Sect. Cyclostigma \\
\hline C. urucurana Baill. & Sect. Cyclostigma \\
\hline C. vulnerarius Baill. & Sect. Cyclostigma \\
\hline C. floribundus Spreng. & Sect. Lasiogyne (Klotzsch) Baill. \\
\hline C. eichleri Müll.Arg. & Sect. Prisci Riina \\
\hline C. priscus Croizat & Sect. Prisci \\
\hline C. thomasii Riina \& P.E.Berry & Sect. Prisci \\
\hline C. oliganthus Müll.Arg. & Sect. Quadrilobi Müll.Arg. \\
\hline C. sapiifolius Müll.Arg. & Sect. Quadrilobi \\
\hline C. piptocalyx Müll.Arg. & Sect. Sampatik (G.L.Webster) Riina \\
\hline
\end{tabular}

been updated since the publication of its second species, so we include a revised description below.

\section{Taxonomic treatment}

\section{Key to the genera of the tribe Crotoneae with arborescent species in the Atlantic Rain Forest}

1a. Inflorescences paniculate; staminate flowers in proximal positions of flower clusters and a single pistillate flower at the distal most position of flower clusters; stamens erect in bud Brasiliocroton

1b. Inflorescences thyrsoid; staminate flowers in distal cymules and pistillate flowers in proximal cymules, sometimes staminate and pistillate flowers occurring together in proximal cymules; stamens inflexed in bud

Croton

\section{Brasiliocroton P.E.Berry \& Cordeiro}

Monoecious trees, usually with clear latex; trichomes dendritic-rosulate, stellate, or stellate-porrect. Leaves alternate, ovate, or occasionally obovate, simple, entire, apex acute to acuminate, base rounded or truncate, venation pinnate, 1(2) pair(s) of acropetiolar glands sessile to stipitate, visible from the adaxial side of the leaves, stipules absent. Inflorescences branched, terminal or axillary, paniculate, unisexual or bisexual; staminate flowers in proximal position of flower clusters and a single pistillate flower at the distal most position of flower clusters. Staminate flowers dichlamydeous, pedicellate, (4-)5(-6)-merous, valvate; nectary disk usually segmented, with 5 glands opposite the each sepal; stamens free, (14-)25(-30), erect in bud; pollen grains spheroidal, inaperturate, with crotonoid exine. Pistillate flowers monochlamydeous or dichlamydeous, pedicellate, valvate; sepals 5, free or basally connate; ovary with 3(4) carpels, 3(4)-locular, locules 1-ovulate; styles 3, bifid, free, or connate into a short column, receptive surface verrucose. Capsules spherical to trigonous, epicarp smooth or muricate; seeds smooth, with caruncle.

Brasiliocroton is sister to Croton (Wurdack et al. 2005; Berry et al. 2005a; Riina et al. 2014), and the two genera share characters such as stellate/dendritic trichomes and petiolar glands (Riina et al. 2014). However, they can be easily distinguished by inflorescence type (ramified in Brasiliocroton vs. not ramified in Croton), position of pistillate flowers (distal cymules in Brasiliocroton vs. proximal 
cymules in Croton), and stamens in bud (erect in Brasiliocroton vs. inflexed in Croton).

\section{Key to the species of Brasiliocroton from the Atlantic Rain Forest}

1a. Indument on young branches whitish to ochraceous; inflorescences terminal, always bisexual; sepals of the pistillate flowers united; capsules smooth, covered by dendritic trichomes

B. mamoninha

1b. Indument on young branches ferrugineous; inflorescences axillary, unisexual or rarely bisexual; sepals of the pistillate flowers free; capsules strongly muricate, covered by stellates trichomes

B. muricatus

Brasiliocroton mamoninha P.E.Berry \& Cordeiro, Syst. Bot. 30(2): 357. 2005.-TYPE: Brasil, Espirito Santo: Marilândia, 6 Dec 1994, J. Pirani, M.A.G. Magenta and A.A. Conceição 3411 (holotype: SPF 00100591!; isotypes: NY 00990756!, SP 000640!, K 000600468!, WIS 0255055!) (Fig. 3a-c).

Vernacular names: Mamoninha, mamona-da-mata.

Treelets to trees 5-7 m tall; branchlets corrugated, glabrescent to pubescent with dendritic trichomes. Leaves with margin entire; glands 2, globose, acropetiolar, sessile or stipitate; petioles cylindrical or corrugated. Inflorescences bisexual, terminal. Staminate flowers with apex of sepals rounded; petals ellipsoid; stamens ca. 25. Pistillate flowers with sepals united at the base, apex acute, petals 5; ovary covered by dendritic or stellate trichomes. Capsules smooth; seeds ovate to oblong.

Phenology: Flowering from January to October; fruiting in February.

Habitats: The species occurs mainly in coastal plateau forests within the ARF, at 60-700 m elevation.

Distribution: Brasiliocroton mamoninha occurs in Brazil in the states of Minas Gerais, Espirito Santo, Bahia and Maranhão. It has a disjunct distribution between the ARF and the eastern Amazonian domain.

Additional specimens studied: Brazil. Bahia: Mucuri, 16 Jul 1968, R.P. Belem 1563 (CEPEC, NY, WIS). Espirito Santo: Linhares, 12 May 1985, G. Martinelli et al. 10971 (RB, K, SI, SP, US). Maranhão: Tuntum, 9 Apr 1974, F. Paiva 58 (PEUFR).

Conservation status: Least Concern (LC) (Berry et al. 2005b).

Notes: Brasiliocroton mamoninha differs from B. muricatus by the presence of corrugated branchlets, dendritic trichomes, terminal and bisexual inflorescences, pistillate flowers with petals present, sepals united at the base, and fruits with a smooth epicarp.

Brasiliocroton muricatus Riina \& Cordeiro, Syst. Bot. 39(1): 230. 2014. - TYPE: Brazil, Bahia: Cruz das Almas, 12 Nov 1983, H.P. Bautista and G.C.P. Pinto 1223 (holotype: HUEFS; isotypes: ALCB [n.v.], RB!, MBM 163003!) (Fig. 3d-g).

Vernacular names: Barba-de-bode, velame, and mamona-da-mata.

Trees 5-20 m tall; branchlets striate; pubescent or glabrous, trichomes stellate. Leaves with margin entire, crenate or serrate, slightly revolute; glands $2(-4)$, acropetiolar, sessile or shortly stipitate, patelliform; petioles striate. Inflorescences unisexual, rarely bisexual, axillary. Staminate flowers with apex of sepals cuneate; petals oblong; stamens 20(-24). Pistillate flowers with free sepals, apex of sepals cuneate; petals absent; ovary covered by stellate trichomes. Capsules muricate; seeds oblong, striate.

Phenology: Flowering in September-November; fruiting in February.

Habitats: The species occurs at the edges of moist forests, seasonally dry forests and secondary forests, at $200-800 \mathrm{~m}$ elevation.

Distribution: Brasiliocroton muricatus occurs in Brazil (Bahia, Minas Gerais and Espirito Santo), exclusively in the ARF.

Additional specimens studied: Brazil. Bahia: Jequié, 22 Nov 2003, G.E.L. Macedo et al. 381 (SP). Espirito Santo: São Gabriel da Palha, 27 Apr 1995, G.F. Àrbocz 1386 (SP). Minas Gerais: Salto da Divisa, 21 Aug 2003, J.A. Lombardi et al. 5337 (SP).

Conservation status: Vulnerable (VU B2ab[iii]) (Riina et al. 2014).

Notes: Brasiliocroton muricatus differs from B. mamoninha by the presence of stellate trichomes, striate branchlets, unisexual and axillary inflorescences, pistillate flowers with free sepals and absence of petals, and fruits with a muricate epicarp.

\section{Croton L.}

A recent and updated description of the genus Croton was provided by van Ee et al. (2011). According to Flora do Brasil 2020 (in construction), Croton has about 100 species in the ARF and is among the 30 most diverse 

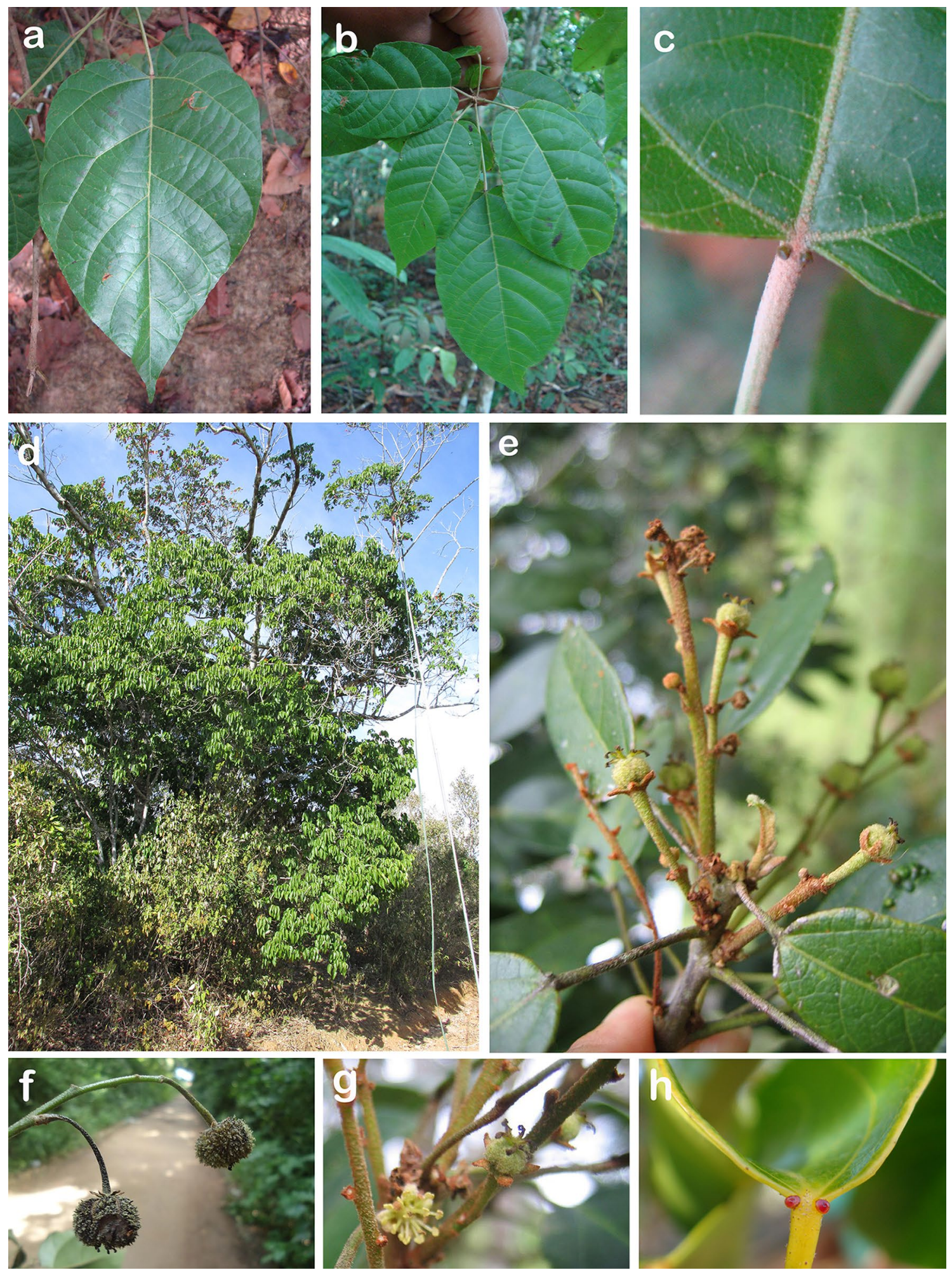

Fig. 3 Brasiliocroton mamoninha a leaf, b sterile branchlet, $\mathbf{c}$ leaf detail showing petiolar glands. Brasiliocroton muricatus d habit, e detail of inflorescences showing young fruits and flower buds, $\mathbf{f}$ mature fruits, $\mathbf{g}$ detail of inflorescence with staminate flower at the base and young fruit, $\mathbf{h}$ detail of leaf showing petiolar glands. a-d R.F. Santos; e-g D.S. Carneiro-Torres; h M.B.R. Caruzo 
genera in number of arborescent species in this domain. Altogether, these 30 genera represent about $40 \%$ of all the tree species diversity in the ARF domain. Croton, with 21 species of trees in the ARF, is outnumbered in this region by much richer genera such as Eugenia (222 spp.), Myrcia (170 spp.), Ocotea (104 spp.), and Miconia (100 spp.)

Many Croton species are used in traditional medicine in Brazil and around the world due to their richness in constituents with biological activities (Salatino et al. 2007). Some tree species occurring in the ARF are commonly used for forest restoration in Brazil (e.g., C. floribundus Spreng., C. piptocalyx Müll.Arg., C. salutaris Casar. and $C$. urucurana Baill.).

\section{Key to the arborescent species of Croton in the Atlantic Rain Forest domain}

1a. Leaves without glands C. floribundus

1b.Leaves with petiolar or basilaminar glands (in $C$. organensis the glands are maculate and inconspicuous)

.. 2

2a. Styles 2 -fid (6 terminal tips; rarely 8 terminal tips in C. sapiifolius)

2b. Styles multifid ( $\geq 12$ terminal tips)) 11

3a. Plants dioecious; flowers 4-merous; ovary 2-locular, rarely 3-locular, seeds $>15 \mathrm{~mm}$ long ..... C. sapiifolius

3b. Plants monoecius; flowers 5-merous; ovary always 3-locular; seeds $<10 \mathrm{~mm}$ long ................................... 4

4a. Petiolar glands stipitate to shortly stipitate ............... 5

4b. Petiolar glands sessile .............................................. 7

5a. Leaves ovate to rounded, membranaceous; calyx lobes of pistillate flowers not foliaceus ... C. pseudopopulus

$5 b$. Leaves obovate-lanceolate or ovate-lanceolate, chartaceous; calyx lobes of pistillate flowers foliaceous ...... 6

6a. Leaves long-petiolate (20-70 mm long); cymules multiflowered; stamens ca. 30

\section{C. macrobothrys subsp. macrobothrys}

6b. Leaves short-petiolate (4-8 mm long); cymules 1-flowered; stamens ca. 11 C. oliganthus

7a. Indument of stellate trichomes; petals reduced to globose-patelliform glands; apex of columella with 3 conspicuous and inflated lobes

C. gracilipes

7b. Indument of dendritic, appressed-stellate, stellatelepidote or stellate trichomes; petals of pistillate flowers filiform, reduced to inconspicuous glands or absent; apex of columella unlobed 8

8a. Plants with clear latex; capsules obovate, deeply 3-sulcate; seeds smooth

C. piptocalyx

8 b. Plants with reddish to ochraceous latex; capsules globose to subglobose; seeds ribbed 9a. Leaves ovate; stipules linear to lanceolate; pistillate flowers with petals reduced to glands or absent C. macrobothrys subsp. septentrionalis

9b. Leaves cordate; stipules subulate or foliaceous; pistillate flowers with filiform petals 10

10a. Stipules foliaceous, broader at the base and filiform at the apical portion; capsules smooth, covered with sessile stellate trichomes

C. urucurana

10b. Stipules not foliaceous; capsules equinate-muricate, covered by conical projections, each with a stipitatestellate trichome at apex C. echinocarpus

11a. Petiolar glands sessile or rarely shortly stipitate ...... 12

11b. Petiolar glands stipitate ........................................... 15

12a. Latex whitish in young branches; indument densely hirsute-tomentose, with long stipitate-stellate, fasciculate and multiradiate trichomes; stamens $>70$ C. medusae

12b. Latex clear or inconspicuos on young branches; indument of pubescent to sparsely pubescent, stellate or dendritic trichomes; stamens ca. 15 ........................ 13

13a. Young branches flattened; leaves ovate-lanceolate to elliptical, basilaminar glands maculate and usually inconspicuos; pistillate flowers flask-shaped C. organensis

13b. Young branches cylindrical; leaves ovate, broadly ovate to elliptical, acropetiolar glands conspicuous; pistillate flowers campanulate ............ 14

14a. Leaves with abaxial surface pubescent; calyx lobes of pistillate flowers united up to half of their length, imbricate; capsules covered with blackish and whitish trichomes C. rottlerifolius

14b. Leaves with abaxial surface sparsely pubescent; calyx lobes of pistillate flowers free, reduplicate; capsules covered wih whitish trichomes

C. thomasii

15a. Trichomes on young branches lepidote ................... 16

$15 \mathrm{~b}$. Trichomes on young branches stellate, multiradiate, appressed-stellate or dendritic ................................ 18

16a. Young branches angular; pistillate flowers flaskshaped; calyx lobes not accrescent ............ C. salutaris

16b. Young branches cylindrical; pistillate flowers campanulate; calyx lobes strongly accrescent ................. 17

17a. Indument rufous-silvery; leaf margin entire; stamens ca. 25; montane wet forests

C. campanulatus

17b. Indument silvery; leaf margin serrate; stamens ca. 15 ; seasonally dry forests

C. hemiargyreus

18a. Leaf indument densely tomentose or pilose; stamens $80-130$

C. vulnerarius

$18 \mathrm{~b}$. Leaf indument pubescent, sparsely pubescent or glabrescent; stamens $15-60$... 19

19a. Indument sparsely pubescent or glabrescent; leaves elliptical to broadly elliptical; stamens 15-20; 

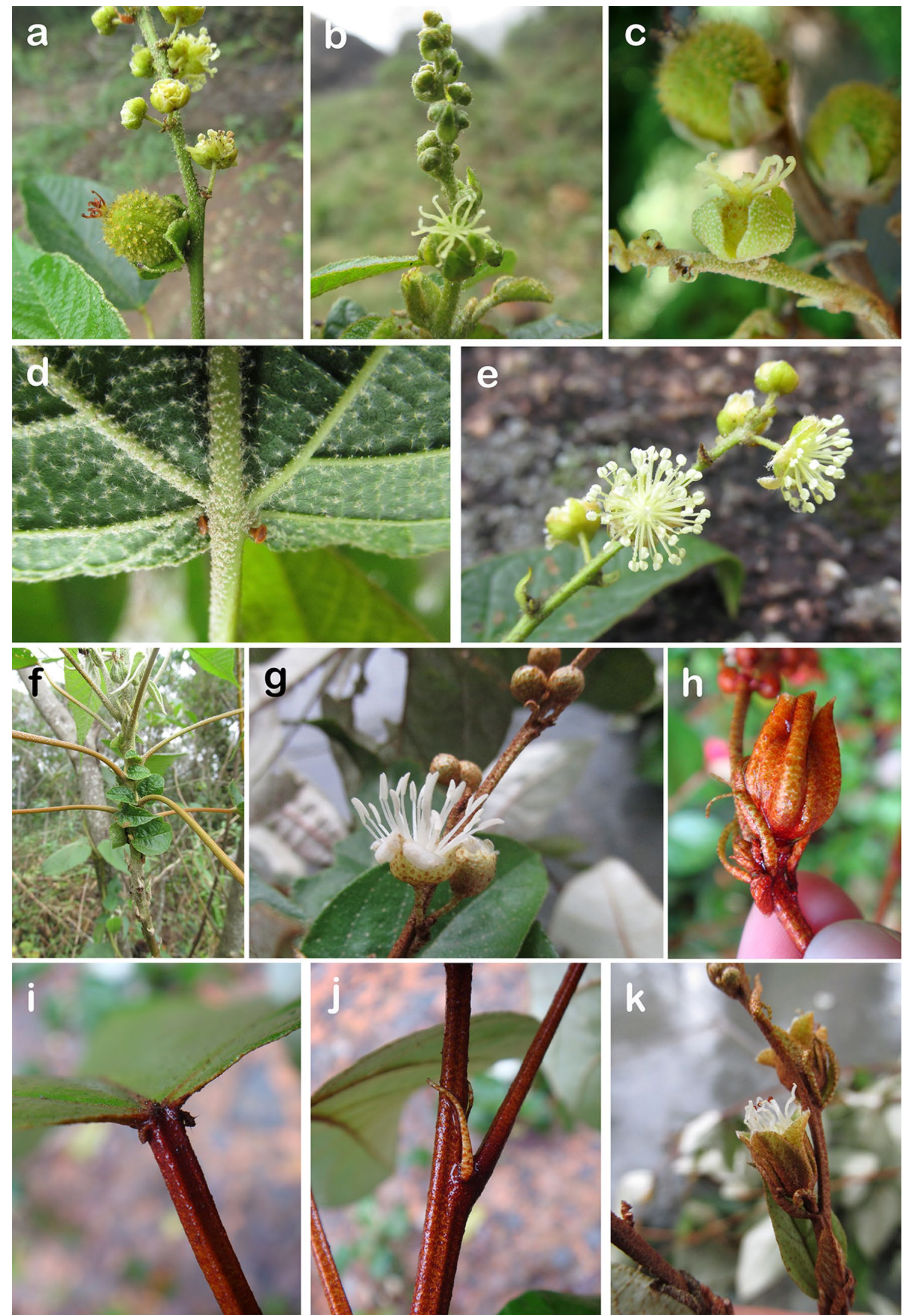
\Fig. 4 Croton alchorneicarpus a detail of inflorescence showing young fruit and staminate flowers, b young inflorescence showing pistillate flower in a proximal cymule, $\mathbf{c}$ pistillate flower, $\mathbf{d}$ leaf detail showing stipitate petiolar glands, e detail of inflorescence showing staminate flowers, f young branchlet showing foliaceous stipules. Croton campanulatus $\mathbf{g}$ detail of inflorescence showing staminate flower, $\mathbf{h}$ young fruit with accrescent calyx, $\mathbf{i}$ petiolar glands, $\mathbf{j}$ detail of branchlet showing subulate stipule, $\mathbf{k}$ detail of inflorescence showing pistilate flowers. $\mathbf{a}, \mathbf{b}, \mathbf{d}-\mathbf{g}, \mathbf{k}$ by R.F. Santos; $\mathbf{c}, \mathbf{h}-\mathbf{j}$ by M.B.R. Caruzo

pistillate flowers pedicellate to long pedicellate; calyx lobes broadly ovate; capsules echinate or muricate 20

19b. Indument pubescent; leaves ovate to cordate; stamens 50-60; pistillate flowers sessile, subsessile or pedicellate; calyx lobes ovate to ovate-lanceolate; capsules smooth 21

20a. Leaf base rounded to obtuse, margin crenate; stamens ca. 20; capsules globose

C. priscus

20b. Leaf base cordate, margin finely serrate; stamens ca. 15; capsules subglobose C. eichleri

21a. Pistillate flowers slightly campanulate, sessile to subsessile; calyx lobes ovate, reduplicate, foliaceous, ca. $8 \mathrm{~mm}$ long; styles slightly united at the base

C. alchorneicarpus

21b. Pistillate flowers rotate, usually pedicellate, rarely subsessile; calyx lobes ovate-lanceolate, valvate, ca. $3 \mathrm{~mm}$ long; styles free

C. celtidifolius

Croton alchorneicarpus Croizat, Darwiniana 6: 451. 1944._-TYPE: Brazil, São Paulo: Campos do Jordão, Feb 1935, M. Kuhlmann s.n. (holotype: SP 000649!; isotypes A [n.v.], SPF 00064976!) (Fig. 4a-f).

Vernacular names: Licurana and sangra d'água.

Trees up to $15 \mathrm{~m}$ tall; latex clear to slightly ochraceous; trichomes on young branches stellate, stellate-porrect, dendritic and dendritic-porrect. Leaves ovate to cordate; adaxial surface glabrous to glabrescent, abaxial surface sparsely pubescent; margin entire to irregularly serrate; glands 2(4), acropetiolar, stipitate, patelliform; stipules lanceolate, linear, sometimes foliaceous. Inflorescences terminal, lax, proximal cymules bisexual. Staminate flowers rotate, long pedicellate; stamens ca. 60. Pistillate flowers subcampanulate, sessile to subsessile, slightly imbricate, calyx ovate, foliaceous, midvein strongly evident; petals filiform; styles with 12 terminal tips, connate at the base, sometimes forming a column. Capsules subglobose, strigose, covered with projections; seeds oblong, ribbed.

Phenology: Flowering from January to December; fruiting in December-March and September.
Habitats: It occurs in montane wet forest and riparian forest, at 800-1900 m elevation.

Distribution: Croton alchorneicarpus is endemic to the "Serra da Mantiqueira" in southeastern Brazil (Minas Gerais, Rio de Janeiro and São Paulo) and is very common in this region.

Additional specimens studied: Brazil. Minas Gerais: Extrema, 13 Sep 2015, R. F. dos Santos et al. 29 (SP). Rio de Janeiro: Itatiaia, 16 Feb 2016, R. F. dos Santos et al. 53 (SP). São Paulo: Campos do Jordão, 07 Feb 2006, R. Riina and M.B.R. Caruzo 1532 (SP).

Conservation status: Vulnerable (VU B2ab[iii]). The species has been collected in fewer than 10 locations and its geographic range is smaller than $2000 \mathrm{~km}^{2}$.

Notes: Croton alchorneicarpus is morphologically most similar to $C$. celtidifolius Baill., as observed by Croizat (1944) and Caruzo (2005). However, both species can be distinguished by a suite of characters (Table 2).

Croton campanulatus Caruzo \& Cordeiro, Brittonia 60(3): 261. 2008.-TYPE: Brazil, Rio de Janeiro: Município de Itatiaia, Parque Nacional do Itatiaia, estrada para a piscina do Maromba, ao longo da estrada, $950 \mathrm{~m}, 22^{\circ} 26^{\prime} 10^{\prime \prime} \mathrm{S}$, 4436'49.4"W, mata atlântica, 6 Feb 2006, M.B.R. Caruzo, R. Riina and N. Camps 93 (holotype: SP 000650!; isotypes: WIS 0258811!, NY 01085730!) (Fig. 4g-k).

Trees up to $8 \mathrm{~m}$ tall; latex reddish; trichomes lepidote, rufous-silvery. Leaves ovate; adaxial surface lepidote, abaxial surface densely lepidote and silvery; margin entire; venation pinnate; glands 2, acropetiolar, stipitate, patelliform; stipules lanceolate, discolorous, usually deciduous. Inflorescences terminal, lax, proximal cymules bisexual. Staminate flowers campanulate; calyx lobes united half of their length; stamens 25. Pistillate flowers campanulate, sessile to shortly pedicellate, calyx lobes imbricate, indument rufous-silvery; petals reduced to inconspicuous glands; styles with 12 terminal tips, united at the base. Capsules globose, smooth, calyx and pedicels strongly accrescent; seeds globose, smooth.

Phenology: Flowering from January to May, September, November, and December; fruiting from March to December.

Habitats: It occurs in montane wet forest between 900 and 1500 m elevation.

Distribution: Croton campanulatus is endemic to the Itatiaia massif in "Serra da Mantiqueira" (Rio de Janeiro and Minas Gerais). 
Additional specimens studied: Brazil. Minas Gerais: Bocaina de Minas, 9 Jan 1988, Pineschi 348 (GUA). Rio de Janeiro: Resende, 15 Feb 2016, R.F. Santos et al. 48 (SP). Conservation status: Croton campanulatus can be considered Vulnerable (VU B2ab[iii]) because it has been collected in fewer than 10 locations and its geographic range is smaller than $2000 \mathrm{~km}^{2}$.

Notes: According to Caruzo et al. (2008) and Caruzo and Cordeiro (2013), Croton campanulatus is morphologically most similar to $C$. hemiargyreus, but can be distinguished from the latter due to its indument (rufous-silvery in $C$. campanulatus vs. silvery $C$. hemiargyreus), leaf margin (entire in C. campanulatus vs. serrate in C. hemiargyreus), stipules (entire and discolorous in C. campanulatus vs. slightly laciniate and concolorous in $C$. hemiargyreus), number of stamens (ca. 25 in C. campanulatus vs. ca. 15 in C. hemiargyreus) and pistillate calyx (foliaceous in C. campanulatus vs. fleshy in $C$. hemiargyreus).

Croton campanulatus is also morphologically similar to Croton salutaris, but both species can be told apart by their petioles (smooth, cylindrical and rufous in $C$. campanulatus vs. ribbed, angled and silvery in C. salutaris), number of stamens (ca. 25 in C. campanulatus vs. ca. 15 in C. salutaris) and the shape of the pistillate calyx (campanulate in C. campanulatus vs. flask-shaped in C. salutaris).

Croton celtidifolius Baill., Adansonia 4: 331. 1864.TYPE: Brazil, Rio de Janeiro: 1816-21, A. Saint-Hilaire cat B2 285 (lectotype: P [n.v.], designated by Smith et al. (1988), second-step lectotype designated here: $\mathrm{P}$ 00623096!; isolectotypes: P 00623095!, SP 417993!); P. Claussen s.n. (syntypes: P [n.v.], W [n.v.]); Serra dos Órgãos, 1833, $M$. Vauthier 93 (syntypes: G-DC 00311468!, GH 00257899!, MPU 014851!, P 00493362!, P 00493363!, SP 000651!, W 0051195!); Serra dos Órgãos, 1838, G. Gardner 618 (syntypes: P 00493364!, P 00493365!, P 00493366!, NY 00246524!, NY 00246523!, K 000186059!, US 00109521!, W 0051196!, W 1889-013284!) (Fig. 5a-d).

Vernacular names: Marmeleiro, necorana, pau-de-sangue, pau-sangue, pau-andrade and sangue-de-drago.

Trees up to $15 \mathrm{~m}$ tall; latex ochraceous to reddish; trichomes on young branches stellate, stellate-porrect, dendritic to dendritic-porrect. Leaves ovate to cordate; adaxial and abaxial surface pubescent; margin entire to irregularly serrate; glands 2(4), acropetiolar, stipitate, patelliform, rarely shortly stipitate; stipules lanceolate to linear, rarely foliaceous. Inflorescences terminal, lax, with proximal cymules bisexual. Staminate flowers rotate, long pedicellate; stamens ca. 55. Pistillate flowers rotate, pedicellate, rarely subsessile, valvate, calyx ovate-lanceolate; petals filiform; ovary subglobose; styles with 12 terminal tips, free. Capsules subglobose, warty, with inconspicuous projections; seeds subglobose, ribbed.

Phenology: Flowering and fruiting from October to May.

Habitats: The species occurs in montane and mixed wet forest, seasonally dry forest, and riparian forest, at $350-1220$ m elevation.

Distribution: Croton celtidifolius is a common species in southeastern and southern Brazil, occurring in the states of Espirito Santo, Minas Gerais, Paraná, Rio de Janeiro, Santa Catarina, São Paulo, and Rio Grande do Sul.

Additional specimens studied: Brazil. Espirito Santo: Santa Tereza, 21 Jan 2015, R.F. Santos et al. 19 (SP). Minas Gerais: Poços de Caldas, 18 Dec 2006, M.B.R. Caruzo and D.A. Ferro 110 (SP). Paraná: Ponta Grossa, 13 Nov 2015, R.F. Santos and A.P. Noronha 36 (SP). Rio de Janeiro: Nova Friburgo, 4 Feb 2006, R. Riina et al. 1520 (SP). São Paulo: Águas da Prata, 13 Jan 2016, R.F. Santos et al. 40

Table 2 Main morphological characters distinguishing Croton alchorneicarpus, C. celtidifolius and C. vulnerarius

\begin{tabular}{llll}
\hline Characters & C. alchorneicarpus & C. celtidifolius & C. vulnerarius \\
\hline Petiolar glands & Sessile or shortly stipitate & Stipitate, rare shortly stipitate & Stipitate \\
Thickness of petiolar glands & Thick & Thick & Filiform \\
Number of stamens & ca. 60 & ca. 50 & $80-130$ \\
Pistillate flower & Sessile or subsessile & Pedicellate, rarely sessile & Sessile \\
Estivation of pistillate flower & Slightly imbricate & Valvate & Reduplicate-valvate \\
Calyx of pistillate flower & Foliaceous & Not foliaceous & Foliaceous \\
Sepals of pistillate flower & Oval & Oval-lanceolate & Oval to oval-lanceolate \\
Petals of pistillate flower & Filiform & Filiform & Lanceolate \\
Calyx & Accrescent & Not accrescent & Slightly accrescent \\
\hline
\end{tabular}


(SP). Santa Catarina: Lauro Muller, 16 Dec 1958, Reitz and Klein 8045 (SP, HBR, MBM). Rio Grande do Sul: Morrinhos do Sul, 16 Dec 1995, J.A. Jarenkow and M. Sobral 2914 (MBM, PEL).

Conservation status: Croton celtidifolius can be considered as Least Concern (LC) because it is relatively widespread and very common in its area of occurrence.

Notes: Croton celtidifolius is morphologically most similar to $C$. alchoneicarpus and $C$. vulnerarius, buf it differs from the last two species in several features (Table 2). Smith et al. (1988) mention that $C$. celtidifolius can be easily confused with $C$. urucurana; however, the two species differ from each other by leaf morphology (ovate in C. celtidifolius vs. cordate in C. urucurana), length of the pedicel of pistillate flowers ( $4 \mathrm{~mm}$ in $C$. celtidifolius vs. $2 \mathrm{~mm}$ in C. urucurana), number of stamens (ca. 50 in $C$. celtidifolius vs. ca. 15 in C. urucurana) and style branching (12 terminal tips in C. celtidifolius vs. 6 terminal tips in C. urucurana).

Smith et al. (1988) designated a lectotype for Croton celtidifolius but they did not select one of the two herbarium sheets deposited at $\mathrm{P}$ as the actual lectotype. Therefore, we indicate here a single sheet and designate a second-step lectotype for this name.

Croton echinocarpus Müll.Arg., Linnaea 34: 88. 1865. Croton verrucosus Radcl.-Sm. \& Govaerts, Kew Bull 52: 198. 1997. nom. superfl.-TYPE: Brazil: s.d., s. col., s.n. (holotype: G-DC 00311425!) (Fig. 5e-h).

Vernacular names: Adrago, capixingui, mangue, sangra d'água, sangue d'água and sangue de drago.

Trees up to $13 \mathrm{~m}$ tall; latex ferrugineous to reddish; trichomes on young branches stellate, multiradiate and dendritic. Leaves cordate; adaxial surface sparsely pubescent, abaxial surface densely pubescent; margin entire; glands 2-4, acropetiolar, sessile, globose; stipules subulate, elongated. Inflorescences terminal, lax, with proximal cymules bisexual. Staminate flowers campanulate, calyx lobes united at base; stamens 20-34. Pistillate flowers rotate, subsessile, valvate; calyx lobes oblanceolate; petals filiform, with glands at apex; styles with 6 terminal tips, united at base. Capsules globose, equinate-muricate, covered with projections ending in long stipitate-multiradiate trichomes; seeds subglobose, ribbed.

Phenology: Flowering from November to May; fruiting from October to June.

Habitats: The species is found in edges of montane wet forest, semideciduous forest, rock outcroppings and riparian forest, at 708-1503 m elevation.
Distribution: Croton echinocarpus is endemic to the ARF. It occurs in southeastern Brazil, in the states of São Paulo [where a population was recently discovered (Caruzo and Santos 2015)], Rio de Janeiro, Minas Gerais and Espirito Santo.

Additional specimens studied: Brazil. Espirito Santo: Ibatiba, 11 Dec 1984, G. Hatschbach and J.M. Silva 48605 (MBM). Minas Gerais: Ouro Branco, 12 May 1990, M.M. Arbo et al. 3970 (SP, SPF, CTES). Rio de Janeiro: Nova Friburgo, 4 Feb 2006, R. Riina et al. 1519 (SP, MICH). São Paulo: Atibaia, 28 Mar 2014, R.F. Santos and O.L.M. Silva 2 (SP).

Conservation status: Caruzo and Santos (2015) categorized the conservation status of Croton echinocarpus as Data Deficient (DD). However, we reevaluated it here as Vulnerable (VU B2ab[iii]), because it has been collected in fewer than 10 locations and its geographic range is smaller than $2000 \mathrm{~km}^{2}$.

Notes: Radcliffe-Smith and Govaerts (1997) created, erroneously, a nomen novum (Croton verrucosus Radcl.-Sm.) to replace the supposedly illegitimate name $C$. echinocarpus Müll.Arg. The mistake comes from the misinterpretation of the protologue of C. agrarius var. echinocarpus (Baillon 1864) where the name "C. echinocarpus" is included in parentheses as follows: " $C$. agrarius var. echinocarpus $(C$. echinocarpus in mss. in herb. Mus.)." Radcliffe-Smith and Govaerts' (1997) acceptance of C. echinocarpus Baill. as a validly published name made $C$. echinocarpus Müll.Arg. illegitimate, and for that reason a new name was necessary (C. verrucosus). We argue that the name $C$. echinocarpus Baill. is not a validly published name under the code, and consequently the name $C$. verrucosus becomes a superfluous name (i.e., illegitimate by definition).

Croton echinocarpus can be distinguished from other arborescent Croton species from the ARF, by the 1 or 2 pairs of globose sessile acropetiolar glands, visible from the adaxial side of the leaf, cordate leaves, subulate stipules, rotate pistillate flowers and equinate-muricate capsules.

Most collections of Croton echinocarpus deposited at VIES herbarium (Espirito Santo) were erroneously identified as Croton cf. pseudopopulus. These two species differ in their petiolar glands (sessile in $C$. echinocarpus vs. stipitate in C. pseudopopulus), leaf margin (entire in $C$. echinocarpus vs. serrate in C. pseudopopulus) and pistillate flowers (sessile in C. echinocarpus vs. pedicellate in C. pseudopopulus).

Croton eichleri Müll.Arg., Fl. Bras. 11(2): 272. 1873.TYPE: Brazil, Minas Gerais: "Habitat ad Porto do Rio 

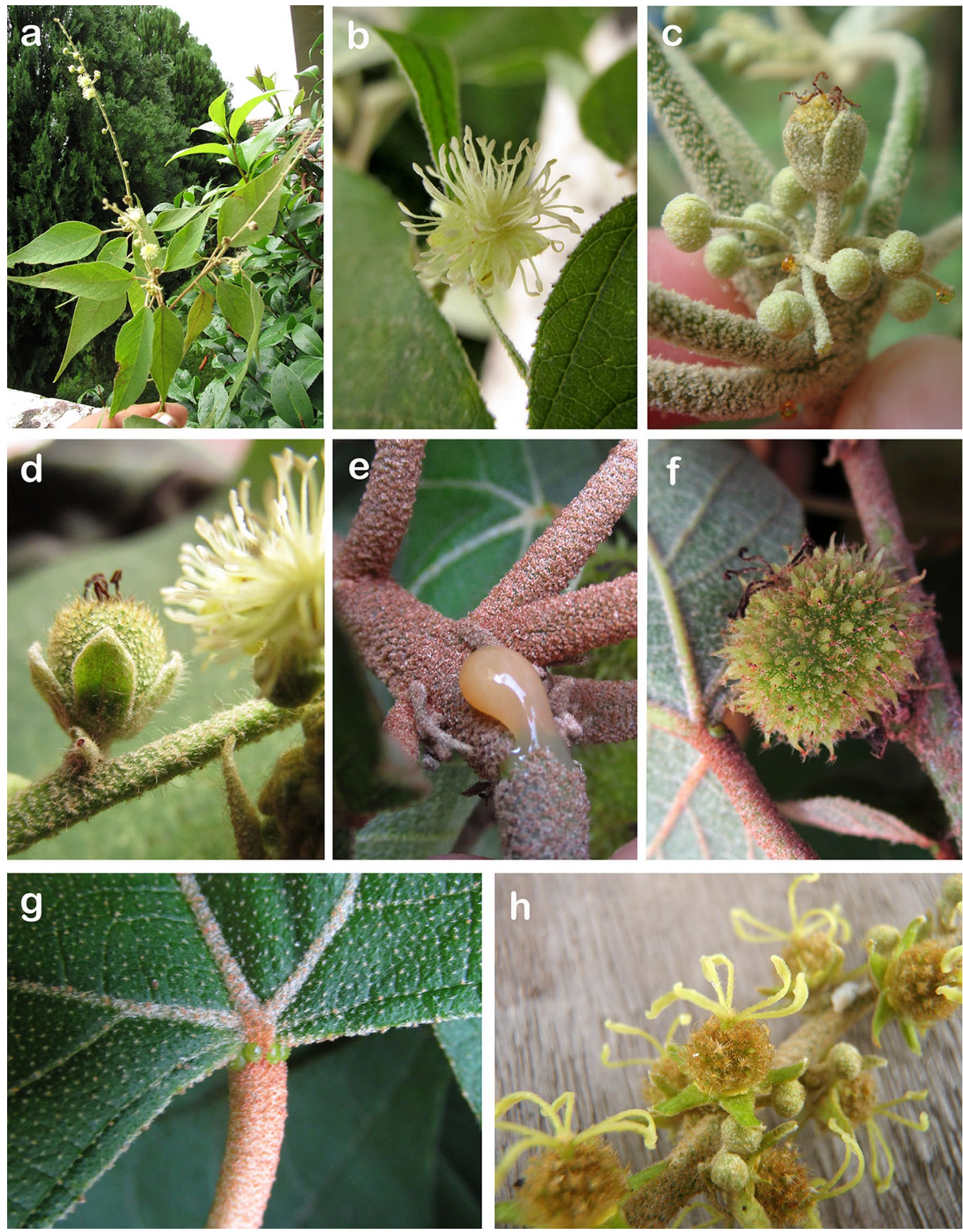

Fig. 5 Croton celtidifolius a branchlet with inflorescence, b staminate flower, $\mathbf{c}$ detail of inflorescence showing floral buds and young fruit, d immature fruit. Croton echinocarpus e detail of branchlet

Cervo inter Ouro fino et Caldas", s.d., A.F. Regnell 242 (lectotype designated here: P 00623149!; isolectotypes A 00257923!, BR 0000008766496!, BR 0000008766823!, showing indumentum and latex, $\mathbf{f}$ fruit, $\mathbf{g}$ petiolar glands, $\mathbf{h}$ detail of inflorescence showing pistillate flowers. $\mathbf{a}, \mathbf{b}, \mathbf{d}-\mathbf{g}$ by R.F. Santos; $\mathbf{c}$ by M.B.R. Caruzo; $\mathbf{h}$ by O.L.M. Silva

C 10011167!, F 0056120F!, F 0093628F!, P 00623148!, S 07-12794!, S 07-12795!, S 07-12796!, S 07-12797!, US 00902151!, US 00902150!) (Fig. 6a-d). 
Trees up to $10 \mathrm{~m}$ tall; latex reddish; trichomes on young branches multiradiate-porrect and appressed-stellate. Leaves ovate to oblong; adaxial surface glabrescent, abaxial surface densely pubescent; margin dentate; glands 2-4, acropetiolar, stipitate to shortly stipitate, patelliform; stipules subulate. Inflorescences terminal, congested, with proximal cymules bisexual. Staminate flowers with ca. 15 stamens. Pistillate flowers campanulate, pedicellate, calyx lobes largely ovate, foliaceous; petals subulate; styles with 12 terminal tips. Capsules subglobose, muricate, covered with projections ending in a multiradiate trichome; seeds subglobose, ribbed.

Phenology: Flowering in December; fruiting in February.

Habitats: According to Stehmann et al. (2009), C. eichleri occurs in seasonally dry forest.

Distribution: Croton eichleri occurs in southern and southeastern Brazil (Minas Gerais, Paraná and Rio de Janeiro). It is an apparelty rare species, known only from a single location in Rio de Janeiro state (Itatiaia), two from Minas Gerais state (one of them is the type locality, Caldas) and six collections from different locations in Paraná state.

Additional specimens studied: Brazil. Minas Gerais: Parque Nacional do Caparaó, 12 Dec de 1988, L. Krieger et al. s.n. (CESJ 23354). Paraná: Ortigueira, 17 Dec 1988, J. Augusto s.n. (R 168461). Rio de Janeiro: Itatiaia, 13 Feb 2016, M.B.R. Caruzo et al. 186 (SP).

Conservation status: Croton eichleri can be categorized as Vulnerable (VU B2ab[iii]) because it has been collected in fewer than 10 locations and its geographic range is smaller than $2000 \mathrm{~km}^{2}$.

Notes: Croton eichleri is morphologically most similar to C. priscus, but both species can be separated by several features (Table 3).

Croton floribundus Spreng., Syst. veg. 3: 873. 1826.TYPE: Brazil, s.d., F. Sellow s.n. (holotype: $\mathrm{B} \dagger$ ); s.loc., s.d., F. Sellow 171 (neotype: SP 001046!, designated by Caruzo and Cordeiro (2007) (Fig. 6e-i).

Vernacular names: Andrajo-branco, capixingui, caixeta, cangreo, lava-prato-branco, marmeleiro-preto, sangue-dedrago and sangra d'água.

Trees up to $15 \mathrm{~m}$ tall; latex clear; trichomes on young branches stellate, stellate-porrect, stellate-lepidote, fasciculate and dendritic. Leaves ovate-lanceolate to elliptic; adaxial surface hispid, abaxial surface sparsely pubescent; margin entire; glands absent; stipules lanceolate, foliaceous, deciduous. Inflorescences terminal, congested, proximal cymules unisexual. Staminate flowers rotate; stamens ca. 15. Pistillate flowers pedicellate, reduplicate-valvate, calyx lobes rounded to rhomboidal, foliaceous, midvein strongly evident; petals filiform; styles multifid, with 12 terminal tips, united into a short column at the base. Capsules subglobose, warty, rarely smooth, trichomes stellate-lepidote stipitate; seeds subglobose, smooth.

Phenology: Flowering from August to December; fruiting from November to April.

Habitats: Croton floribundus is a pioneer species, very common in forest edges and clearings in wet forest and seasonally dry forest, at 25-1260 m elevation.

Distribution: The species occurs in Brazil (Alagoas, Bahia, Ceará, Distrito Federal, Espirito Santo, Minas Gerais, Mato Grosso, Mato Grosso do Sul, Paraíba, Paraná, Pernambuco, Rio de Janeiro and São Paulo) and Paraguay (Guadalupe).

Additional specimens studied: Brazil. Alagoas: Ibateguara, 13 Mar 2010, F. Cavalcante and M.C.S. Mota 331 (MAC). Bahia: Arataca, 6 Feb 2015, R.F. Santos et al. 27 (SP). Ceará: Guaramiranga, 17 Feb 1992, M.A. Figueiredo s.n. (IPA 64244, EAC). Distrito Federal: Macedo Novo, 30 Aug 1949, A.P. Duarte s.n. (RB 282717). Espirito Santo: Santa Tereza, 21 Jan 2015 R.F. Santos et al. 13 (SP). Minas Gerais: Itabirito, 2 Feb 2007, M.S. Mendes et al. s.n. (BHCB 113210). Mato Grosso: Próximo de Ivinhema, Nov 1981, P.P. Furtado 102 (RB). Mato Grosso do Sul: Jatei, 11 Dec 1993, M.C. S. Stevaux 825 (HUM, HNUP). Pernambuco: Jaqueira, 29 May 2012, B.S. Amorim et al. 1563 (UFP). Rio de Janeiro: Resende, 13 Feb 2016, R.F. Santos et al. 51 (SP). São Paulo: Jundiai, 2 Feb 2014, R.F. Santos 3 (SP). Paraguay. Guadalupe, Oct 1978, M. Bernardi 18254 (MBM).

Conservation status: Croton floribundus can be categorized as Least Concern (LC) because it is widely distributed and very common in its area of occurrence, besides having several populations found in protected areas of southeastern Brazil.

Notes: Croton floribundus differs from the other arborescent Croton from the ARF by the absence of petiolar glands its hispid adaxial leaf surface.

Croton gracilipes Baill., Adansonia 4: 333. 1864.TYPE: Brazil, Minas Gerais: s.d., P. Claussen 773 (lectotype: P [n.v.], designated by Caruzo and Cordeiro (2007: 579), second-step lectotype designated here: $P$ 00493373!; isolectotype: P 00493372!); Mato Grosso, s.d., C. Gaudichaud-Beaupré 250 (syntype: P 00493374!) (Fig. 7a-d).

Shrubs and trees up to $7 \mathrm{~m}$ tall; latex clear; trichomes on young branches stellate and stipitate-stellate. Leaves ovate 

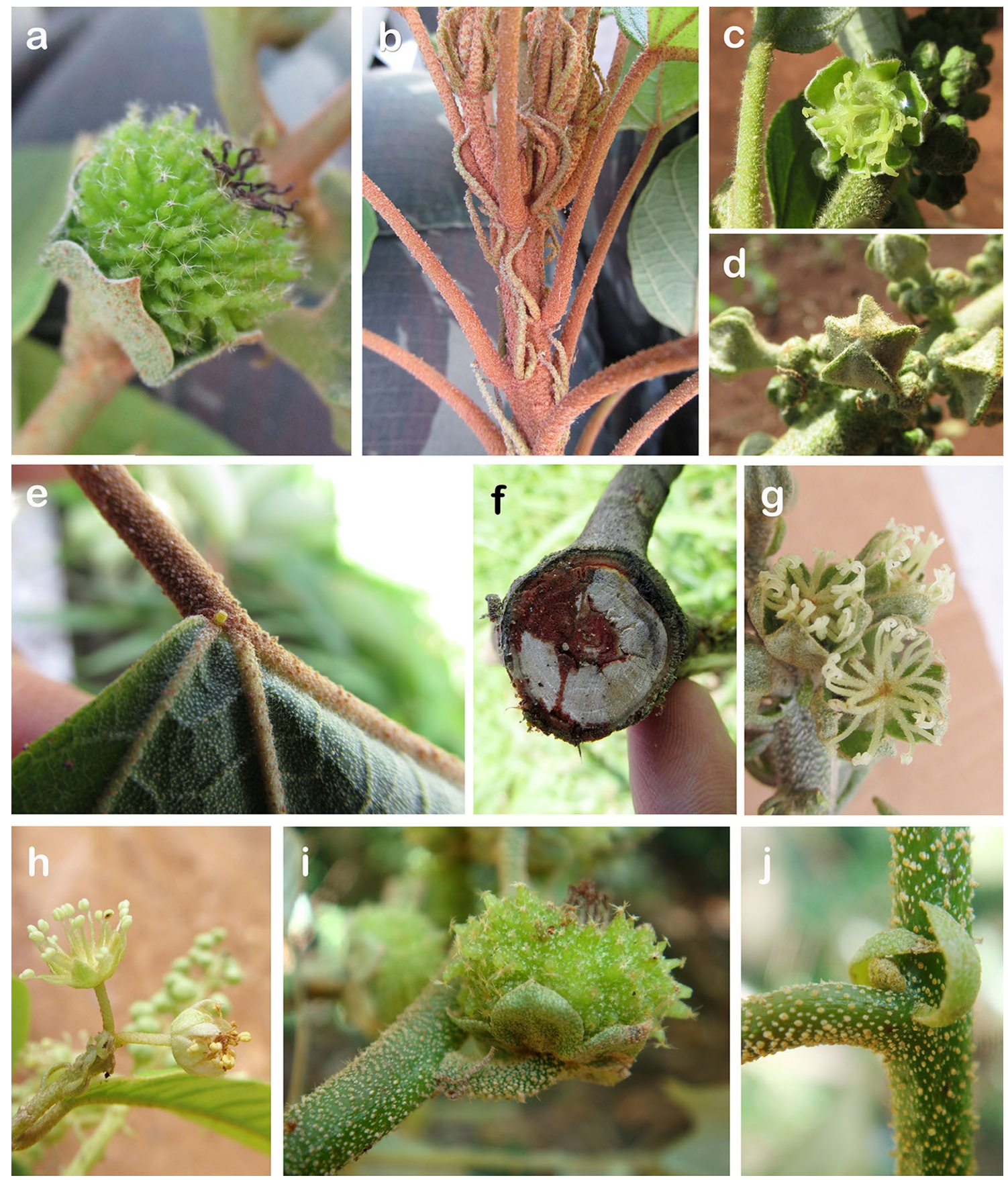

Fig. 6 Croton eichleri a fruit, $\mathbf{b}$ detail of branchlet showing stipules, $\mathbf{c}$ detail of young inflorescence showing a pistillate flower, $\mathbf{d}$ detail of inflorescence showing floral buds with conduplicate calyx, e petiolar gland, $\mathbf{f}$ cross section of branch showing reddish latex. Croton flori-

to cordate; adaxial surface sparsely pubescent to glabrescent, abaxial surface pubescent to densely pubescent; margin serrate to inconspicuosly serrate; glands 2, basilaminar, sessile, globose or patelliform; stipules ca. $1 \mathrm{~mm}$ long, filiform, sometimes with a gland at the apex and/or at the base. Inflorescences terminal, lax, axis flattened, proximal cymules unisexual. Staminate flowers rotate, calyx bundus $\mathbf{g}$ detail of inflorescence showing pistillate flowers, $\mathbf{h}$ staminate flowers, $\mathbf{i}$ detail of fruit showing calyx lobes and pedicel, $\mathbf{j}$ detail of branchlet showing stipules. $\mathbf{a}, \mathbf{b}, \mathbf{e}, \mathbf{f}, \mathbf{h}$ : R.F. Santos; $\mathbf{c}, \mathbf{d}, \mathbf{g}$ : A.P.N. Pereira; i, j: M.B.R. Caruzo

membranous; stamens ca. 18. Pistillate flowers rotate, subsessile, valvate, calyx lobes triangular or lanceolate; petals reduced to conspicuous globose glands; styles with 6 terminal tips, free to slightly united at the base. Capsules obovate, smooth; seeds subglobose, verrucose.

Phenology: Flowering in August, December, and May; fruiting from August to April. 
Table 3 Main morphological characters distinguishing Croton eichleri and C. priscus

\begin{tabular}{lll}
\hline Characters & C. eichleri & C. priscus \\
\hline Petiolar glands & $\begin{array}{c}\text { Stipitate, some- } \\
\text { times sessile }\end{array}$ & Stipitate \\
Shape of petiolar glands & $\begin{array}{l}\text { Patelliform } \\
\text { Leaf shape }\end{array}$ & Globose \\
Leaf margin & Cordate & Obovate to long elliptic \\
Styles & Dentate & Crenate \\
Capsules & 6 terminal tips & 12 terminal tips \\
\hline
\end{tabular}

Habitats: The species occurs in seasonally dry forest, at 60-1000 m elevation.

Distribution: Croton gracilipes is found in Argentina (Corrientes and Jujuy), Bolivia (Santa Cruz de la Sierra), Brazil (Distrito Federal, Mato Grosso do Sul, Minas Gerais, Paraná and São Paulo) and Paraguay (Cordillera and Presidente Hayes).

Additional specimens studied: Argentina. Corrientes: San Cosme, 19 Feb 2004, L.R. Lima et al. 345 (SPF). Jujuy: Ledesma, 20 Oct 1976, A.L. Cabrera et al. 28020 (SP, SI). Bolivia. Santa Cruz: Andres Ibanez, 24 May 1991, M. Nee 40550 (SP, NY, MAD). Brazil. Distrito Federal: Brasilia, 2 Dec 1980, E.P. Heringer et al. 5813 (UEC, IBGE). Minas Gerais: Cabeceira Grande, 19 May 2003, A.A. Santos 2005 (HUEFS, CEN). Goiás: Nova Roma, 3 Dec 2003, R. Mello-Silva et al. 2275 (SPF, RB). Mato Grosso do Sul: Porto Martinho, 5 Dec 2007, A.L.B. Sartori et al. 1082 (SP, CGMS). Paraná: Fênix, 18 Apr 2013, E.L. Siqueira et al. 655 (UEC, HCF). São Paulo: Iperó, 10 Feb 2016, R.F. Santos et al. 44 (SP). Paraguay. Cordillera: Caacupe, 9 Feb 1984, W. Hahn 2015 (SP, MO, PY). Presidente Heyes: Rio Negro, 25 Jul 1995, M.R.P. da Silva and E. Zardini 2192 (SPF).

Conservation status: Croton gracilipes can be categorized as Least Concern (LC) because of its wide extent of occurrence with numerous locality records.

Notes: Croton gracilipes differs from other arborescent Croton from the ARF by the petals reduced to conspicuous globose glands in the pistillate flowers, often visible to the naked eye. The species is vegetatively very similar to $C$. urucurana, differing from it by stipule morphology (stipule ca. $5 \mathrm{~mm}$ long, with a broad foliaceous base and filiform apex in $C$. urucurana vs. ca. $1 \mathrm{~mm}$ long and filiform in $C$. gracilipes) and the conspicuous 3-lobed apex of the columella, which is absent in $C$. urucurana.

Caruzo and Cordeiro (2007) designated a lectotype for Croton gracilipes but they did not select one of the two herbarium sheets deposited at $\mathrm{P}$ as the actual lectotype.
Therefore, we indicate here a single sheet and designate a second-step lectotype for this name.

Croton hemiargyreus Müll.Arg., Linnaea 34: 81. 1865.-TYPE: Brazil, Minas Gerais: Caldas, s.d., A.F. Regnell 402 (lectotype: S, designated by Caruzo and Cordeiro (2007), second-step lectotype designated here: S0712788!; isolectotypes: A 00257935!, BR 0000008768551!, BR 0000008766168!, BR 0000008766045!, BR 0000008762078!, C 10011173!, C 10011174!, F!, G!, GH!, K 000186074!, M 0089104!, NY!, P 00623559!, P 00623560!, P 00623561!, R 000100780!, R 000100780a!, S-R-10525! US!, WU!); s.loc., 1845, J.F. Widgrem 339 (syntypes: A!, BR 0000008768803!, GH 00047313!) (Fig. 7e-h).

Vernacular names: Marmeleiro de brejo.

Trees up to $10 \mathrm{~m}$ tall; latex clear; trichomes on young branches lepidote to lepidote-porrect. Leaves ovate to cordate; adaxial surface glabrescent, abaxial surface densely lepidote, silvery; margin serrate; glands 2, acropetiolar, stipitate, patelliform; stipules linear-lanceolate, deciduous. Inflorescences terminal, lax, axis flattened, proximal cymules bisexual. Staminate flowers campanulate, calyx lobes triangular, united up to half of their length; stamens ca. 15. Pistillate flowers campanulate, shortly pedicellate, calyx lobes broadly ovate, united up to half of their length, margin reflexed; petals reduced to ellipsoid glands; styles with 12 terminal tips, united at the base. Capsules globose, smooth, calyx and pedicels strongly accrescent; seeds globose-ellipsoid, slightly ribbed.

Phenology: Flowering from December to April; fruiting from January to April.

Habitats: The species occurs in open wet forest, at 920-1100 m elevation.

Distribution: Croton hemiargyreus is endemic species to the ARF, with a disjunct distribution between open wet forest ("brejos de altitude") in Pernambuco state and montane wet forest in southeastern Brazil, in the states of São Paulo, Rio de Janeiro and Minas Gerais (Caruzo and Cordeiro 2013).

Additional specimens studied: Brazil. Minas Gerais: Caldas, 14 Jan 2016, R.F. Santos et al. 43 (SP). Pernambuco: Brejo da Madre de Deus, 8 Apr 2008, M.B.R. Caruzo and D.A. Ferro 116 (SP). São Paulo: São Roque da Fartura, 13 Jan 2016, R.F. Santos et al. 42 (SP).

Conservation status: Croton hemiargyreus can be categorized as Vulnerable (VU B1ab[iii]) because it has been 

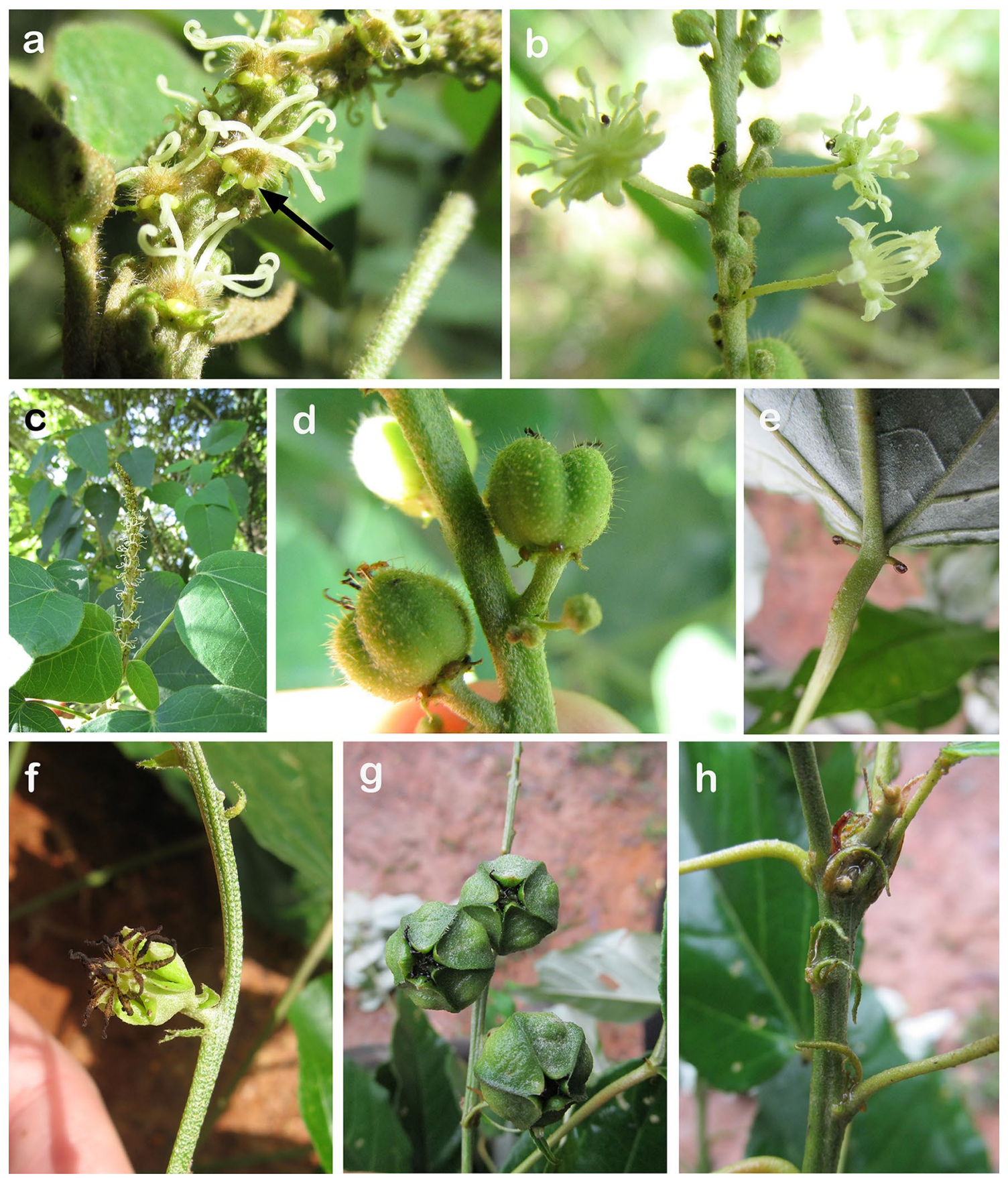

Fig. 7 Croton gracilipes a detail of inflorescence showing pistillate flowers with petals reduced to conspicuous glands (floral nectaries), b detail of inflorescence showing staminate flowers, $\mathbf{c}$ branchlet with inflorescence, $\mathbf{d}$ fruits, notice the tiny calyx. Croton hemiargyreus $\mathbf{e}$ petiolar glands, $\mathbf{f}$ pistillate flower, $\mathbf{g}$ detail of inflorescence with young fruits showing the accrescent and fleshy calyx, $\mathbf{h}$ detail of branchlet showing stipules. a-e, $\mathbf{g}, \mathbf{h}$ by R.F. Santos; f by M.B.R. Caruzo

color (silvery in $C$. hemyargyreus vs. rufous-silvery in $C$. salutaris), petiole morphology (cylindrical in $C$. hemiargyreus vs. angled in $C$. salutaris), leaf margin (serrate in $C$. hemiargyreus vs. entire in $C$. salutaris) and pistillate flowers (campanulate in $C$. hemiargyreus vs. flask-shaped in C. salutaris). Croton hemiargyreus is also morphologically similar to $C$. campanulatus, but differs from it by 
several morphological features (see comments under $C$. campanulatus).

We selected a single herbarium sheet and designated the second-step lectotype for this name, as in Croton gracilipes (see comments under $C$. gracilipes).

Croton macrobothrys Baill., Adansonia 4: 333. 1864.TYPE: Brazil, Rio de Janeiro: Serra dos Órgãos, 1833, $M$. Vauthier 92 (lectotype: P 00633413!, designated by Caruzo et al. (2016); isolectotypes: F 0056158F!, G 00434542!, GH 00257954!, G-DC 00311416!, G-DC 00311415!, MPU 014844!, P 00633414!, P 00633415!).

Vernacular names: Lava-prato, pau-sangue, pau-de-sangue, sangue-de-drago, sangueiro, sangra-d'água, velame and velame-do-mato.

Trees up to $25 \mathrm{~m}$ tall; latex reddish; trichomes on young branches stellate-lepidote, stellate-porrect. Leaves ovate to ovate-lanceolate; apex atenuate to acuminate, base rounded to obtuse; adaxial surface glabrate, glabrescent to sparsely pubescent, abaxial surface glabrate to glabrescent or lepidote to sparsely lepidote; margin entire to irregularly serrate; glands 2, acropetiolar, stipitate to sessile, patelliform; stipules linear to lanceolate. Inflorescences terminal, lax, proximal cymules bisexual. Staminate flowers rotate, long pedicellate, calyx lobes ovate, with an evident midvein; stamens ca. 30. Pistillate flowers rotate, long pedicellate, valvate, calyx lobes spathulate, ovate to obovate, midvein sometimes evident; petals reduced to clavate glands, usually inconspicuous or occasionally absent; styles with 6 terminal tips, free or slightly united at the base. Capsules globose to transverse-ellipsoid, smooth; seeds elliptic to widely elliptic, slightly ribbed.

Habitats: The species occurs in wet forest, at $50-1100 \mathrm{~m}$ elevation.

Distribution: Croton macrobothrys is endemic to the Brazilian ARF, and it occurs in the states of Paraná and Santa Catarina, São Paulo, Rio de Janeiro, Minas Gerais, Bahia, and Alagoas.

Notes: Croton macrobothrys is morphologically most similar to $C$. oliganthus, but both species can be distinguished by diferences in stipules (linear to lanceolate in $C$. macrobothrys vs. subulate in $C$. oliganthus), leaf margin (entire to irregularly serrate in C. macrobothrys vs. crenate in C. oliganthus), size of petioles ( $2-7 \mathrm{~cm}$ long in $C$. macrobothrys vs. $0.6-0.8 \mathrm{~cm}$ long in $C$. oliganthus) and number of stamens (ca. 30 in C. macrobothrys vs. ca. 11 in C. oliganthus).

Some traits (e.g., leaf margin and petiolar glands) vary considerably within Croton macrobothrys. Besides its high morphological variability, a geographic discontinuity in its distribution was recently discovered and two subspecies are currently recognized (Caruzo et al. 2016).

\section{Croton macrobothrys subsp. macrobothrys (Fig. 8a-g).}

Leaves ovate-lanceolate; adaxial surface glabrate, glabrescent to sparsely pubescent, abaxial surface glabrate to glabrescent; margin irregularly serrate; 1 pair of stipitate patelliform acropetiolar glands. Pistillate flowers with calyx lobes spatulate or obovate; styles usually slightly united at the base.

Phenology: Flowering from September to December; fruiting from October to May.

Habitats: Croton macrobothrys subsp. macrobothrys is found typically in edge of montane wet forest, at 50-1100 m elevation.

Distribution: It is found in southern and southeastern Brazil (Paraná, Rio de Janeiro, Santa Catarina and São Paulo states).

Additional specimens studied: Brazil. Paraná: Cerro Azul, 16 Dec 1992, G. Hatschbach and O.S. Ribas 58455 (MBM, ESA, SPF). Rio de Janeiro: Teresópolis, 5 Feb 2006, $R$. Riina et al. 1522 (SP). Santa Catarina: Rancho Queimado, Dec 2012, G. Hatschbach et al. 71575 (MBM). São Paulo: Santo André, 3 Nov 2015, R.F. Santos et al. 32 (SP).

Conservation status: Croton macrobothrys can be categorized as Least Concern (LC) because it is widely distributed and has relatively large populations, some of which are found in several protected areas in southeastern Brazil.

Croton macrobothrys subsp. septentrionalis Caruzo \& R.F.Santos, Phytotaxa 273(1): 54. 2016.-TYPE: Brazil, Bahia: Itacaré, 4 Feb 2015, R.F. Santos et al. 24 (holotype: SP!; isotypes: MBM!, NY!, RB!) (Fig. 8h-m).

Leaves ovate; adaxial surface glabrate to glabrescent, abaxial surface lepidote to sparsely lepidote, sometimes with brownish trichomes; margin entire; 1 pair of sessile patelliform acropetiolar glands. Pistillate flowers with calyx lobes ovate; styles free from the base.

Phenology: Flowering from October to December and May; fruiting from January to May.

Habitats: It occurs at edges of wet forest, at $100-1000 \mathrm{~m}$ elevation.

Distribution: Croton macrobothrys subsp. septentrionalis occurs in northern ARF (northeastern Minas Gerais, southern Bahia and Alagoas). 

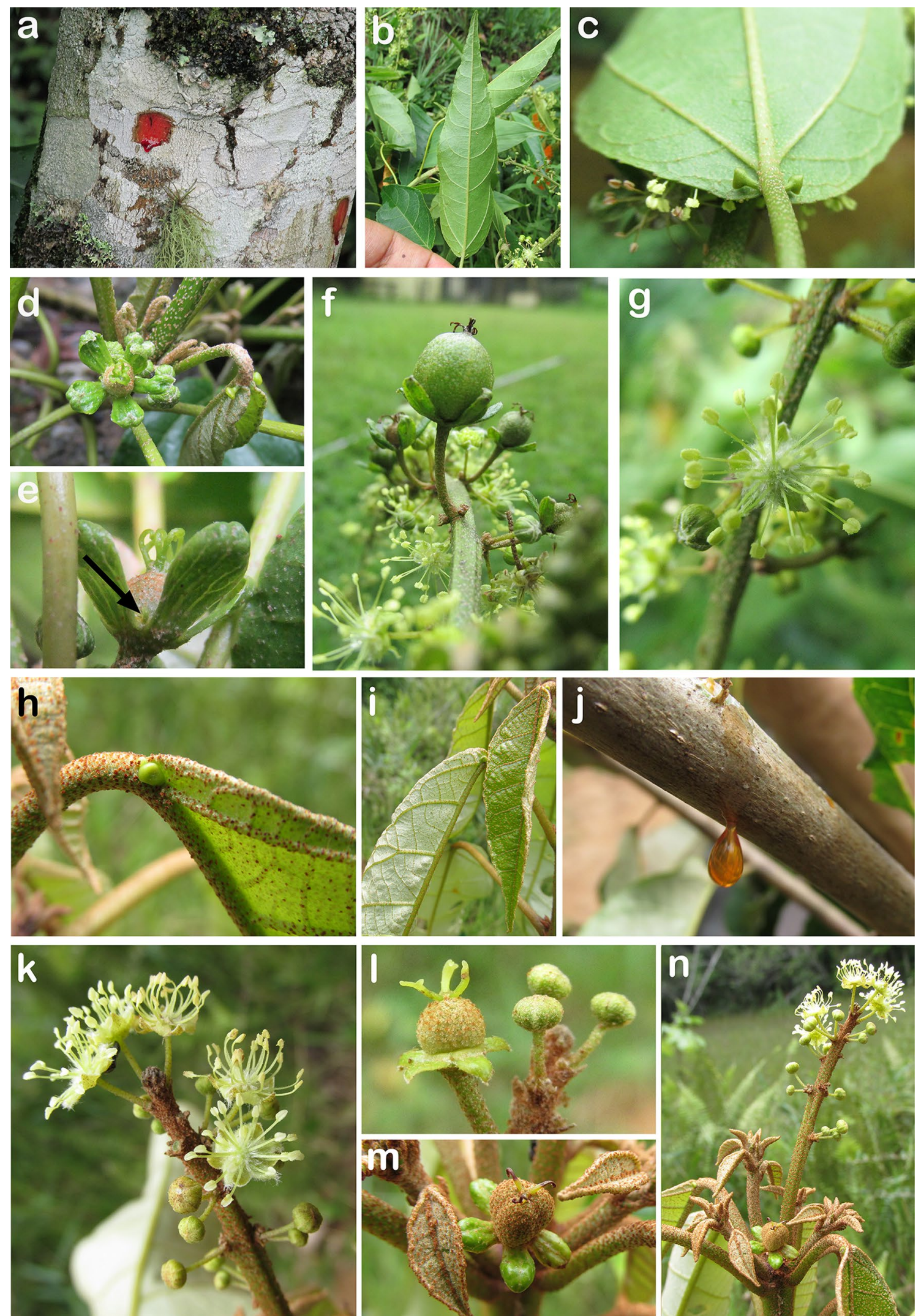
४Fig. 8 Croton macrobothrys subsp. macrobothrys a red latex from cuts on the trunk, b leaf abaxial surface, $\mathbf{c}$ stipitate petiolar glands, $\mathbf{d}$ pistillate flower, e detail of pistillate flower showing reduced petals, $\mathbf{f}$ detail of the inflorescence with young fruits, $\mathbf{g}$ staminate flower. Croton macrobothrys subsp. septentrionalis $\mathbf{h}$ petiolar glands, $\mathbf{i}$ adaxial and abaxial leaf surface, $\mathbf{j}$ branchlet showing reddish latex, $\mathbf{k}$ detail of inflorescence showing staminate flowers, l detail of inflorescence showing pistillate flower and flower buds, m young fruit with persistent styles, $\mathbf{n}$ detail of inflorescence showing young fruit and staminate flowers. $\mathbf{a}-\mathbf{n}$ by R.F. Santos

Additional specimens studied: Brazil. Alagoas: Quebrangulo, 7 Dec 2014, L. Nusbaumer and A. Cailliau 4530 (G, JPB, K, MAC, NY, P, UFP). Bahia: Arataca, 6 Feb 2015, R.F. Santos et al. 27 (SP). Minas Gerais: Santa Maria do Salto, 8 Feb 2006, A.M. Amorim et al. 5574 (CEPEC, NY).

Conservation status: Croton macrobothrys subsp. septentrionalis can be categorized as Vulnerable (VU B2ab[iii]) because it has been collected in less than 10 locations and its geographic range is inferior to $2000 \mathrm{~km}^{2}$.

Croton medusae Müll.Arg., DC. Prodr. 15(2): 530. 1866.-TYPE: Brazil, Minas Gerais: s.d., J.F. Widgren 1110 (holotype: G-DC 00311470!) (Fig. 9a-h).

= Croton caldensis Müll.Arg., Fl. Bras. 11(2): 93. 1873.TYPE: Brazil, Minas Gerais: Caldas, 1862, A.F. Regnell 1080 (lectotype designated here: S 07-12799!; isolectotypes: BR 0000008761309!, G00434450!, K 000186063!, P 00634559!, P 00634560!, R 000100762!, R 000100762a!, R 000100762b!, S S-R-10500!,US 00109516!, US 00997747 !), syn. nov.

= Croton plagiograptus Müll.Arg., Fl. Bras. 11(2): 93. 1873.-TYPE: Brazil, Minas Gerais: Caldas, 1862, A.F. Regnell 1079 (lectotype designated here: S S-R-10558!; isolectotypes: BR 0000008760951!, G 004346444!, S 07-12777!, US 00109647!), syn. nov.

= Croton glaziovii Müll.Arg., Fl. Bras. 11(2): 93. 1873.TYPE: Brazil, Rio de Janeiro: s.d., A. Glaziou 2691 (holotype: P 00623600!; isotype: BR 0000008763907!), syn. nov.

Vernacular names: Mijo-de-gato.

Trees up to $6 \mathrm{~m}$ tall; latex whitish in young branchlets, reddish in the trunk; indument hirsute-tomentose of fasciculate, multiradiate and stellate-porrect, long stipitate, ochraceous trichomes. Leaves cordate; adaxial surface glabrescent, abaxial surface tomentose; margin dentate; glands 2-4, acropetiolar, shortly stipitate, patelliform; stipules elongated, lanceolate, entire to laciniate. Inflorescences terminal, congested, proximal cymules bisexual; bracts usually laciniate. Staminate flowers rotate, long pedicellate, calyx lobes ovate; stamens 70-100. Pistillate flowers campanulate, shortly pedicellate, calyx lobes ovate to broadly ovate, foliaceous, imbricate; petals reduced, filiform, uneven in length, pilose at the apex; styles with 12 terminal tips. Capsules rounded, with projections in the surface; seeds not seen.

Phenology: Flowering in August and from December to April; fruiting from December to April.

Habitats: Croton medusae is a rare species growing in gaps and edges of wet and seasonally dry forests, at 546-1300 m elevation.

Distribution: It is distributed in southeastern Brazil, in the states of Minas Gerais, Rio de Janeiro and Espirito Santo.

Additional specimens studied: Brazil. Espirito Santo: $16 \mathrm{~km}$ antes de Rio Novo, 20 Dec 1966, L. Emygdio et al. 2525 (R). Minas Gerais: Teófilo Otoni, 8 Jan 2011, L.F.A. de Paula et al. 156 (RB, BHCB). Rio de Janeiro: Nova Friburgo, 4 Feb 2006, R. Riina et al. 1521 (SP, MICH).

Conservation status: Croton medusae can be categorized as Vulnerable (VU B2ab[iii]) because it has been collected in less than 10 locations and its geographic range is inferior to $2000 \mathrm{~km}^{2}$.

Notes: Croton caldensis, C. plagiograptus and C. glaziovii are here synonymized under $C$. medusae. The analysis of type specimens, other specimens, and protologues of all the binomials involved revealed that the diagnostic characteristics of these taxa greatly overlap and render species identification impossible using morphological data alone.

Croton medusae can be easily recognized by its whitish latex in young branches, an unusual character in Croton species, dense and thick indument of generally long stipitate, fasciculate, multiradiate and stellate-porrect trichomes, elongate stipules, shortly pedicellate pistillate flowers and surface of capsules with projections.

Croton oliganthus Müll.Arg., Linnaea 34: 106. 1865.TYPE: Brazil. "inter Bahia et Vittoria", s.d., F. Sellow s.n. (holotype: G 00434596!; isotypes B 100127730!, A 00047368!); Bahia, Boa Nova, Parna Boa Nova, Fazenda Alvorada, região do Campo Belo, BR 030 entre Boa Nova a BR 116, ca. $10 \mathrm{~km}$ do centro de Boa Nova, ramal de acesso a Manuel Vitorino, $14^{\circ} 21^{\prime} 25^{\prime \prime} \mathrm{S}$ e $40^{\circ} 12^{\prime} 46^{\prime \prime} \mathrm{W}$, alt. $900-$ 900 m, 7 Feb 2013, A.M. Amorim et al. 8223 (epitype designated here: RB 582151!; isoepitype CEPEC 135845).

Vernacular names: Laranjeira.

Trees up to $8 \mathrm{~m}$ tall; trichomes on young branches appressed-stellate to stellate-lepidote. Leaves obovate-lanceolate to narrowly elliptic, base sometimes asymmetric, shortly petiolate; adaxial and abaxial surface glabrescent; 

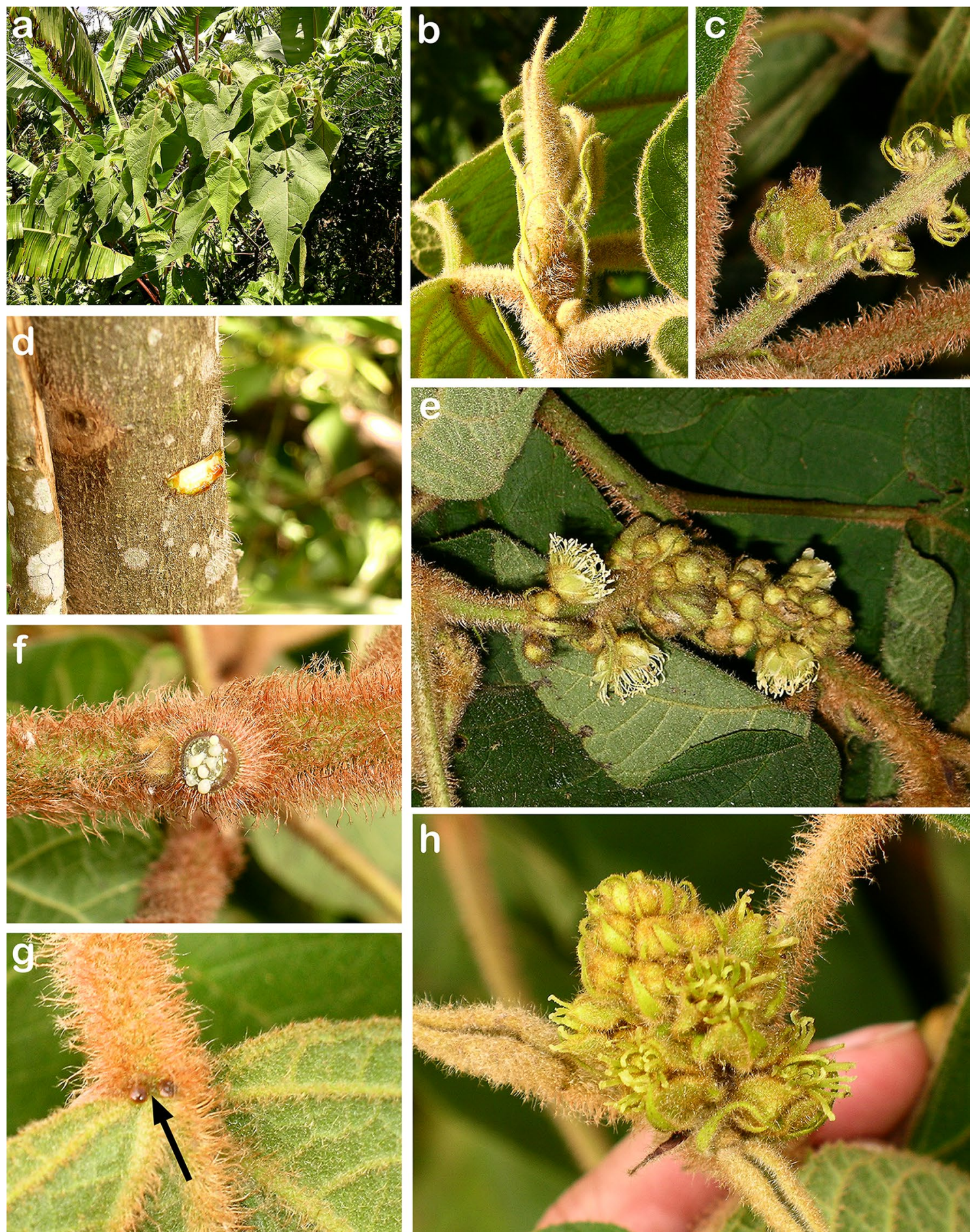

Fig. 9 Croton medusae a young branch, b detail of branchlet showing stipules, $\mathbf{c}$ detail of inflorescence showing young fruit and persistent laciniate bracts, $\mathbf{d}$ reddish latex from the trunk, e inflorescence showing staminate flowers and flower buds, f young branchlet with

margin entire to sinuous; glands 2, acropetiolar, shortly stipitate, patelliform; stipules subulate. Inflorescences terminal, lax, proximal cymules bisexual. Staminate flowers rotate; stamens ca. 11. Pistillate flowers rotate, pedicellate, whitish latex, $\mathbf{g}$ petiolar glands and surrounding indumentum of long stipitate trichomes, $\mathbf{h}$ young inflorescence with pistillate flowers at the base. $\mathbf{a}-\mathbf{h}$ by R. Riina

valvate, calyx lobes ovate-triangular, margin slightly revolute; styles with 6 terminal tips, united at the base. Capsules elliptic, smooth; seeds oblong, smooth. 
Phenology: Flowering and fruiting from June and January to February.

Habitats: The species occurs in wet forest.

Distribution: Croton oliganthus is endemic to the ARF and it occurs in the states of Rio de Janeiro, Espírito Santo, and Bahia.

Additional specimens studied: Brazil. Bahia: Santa Cruz Cabrália, 13 Apr 1988, F.S. Santos 863 (CEPEC, SCFS). Rio de Janeiro: Rio de Janeiro, s.d., M. Kuhlmann s.n. (RB 111127, DAV 70616).

Conservation status: Croton oliganthus can be categorized as Data Deficient (DD) due to the few collections known to date.

Notes: The species can be considered the most poorly known arborescent Croton species in the ARF. There are only four collections of this taxon available in herbaria, which hinder a deeper understanding of its morphological variation. Croton oliganthus can be distinguished from the other species treated here by its shortly petiolate and obovate-lanceolate to narrowly elliptic leaves, sometimes with asymmetric base, and its inflorescences with bisexual proximal cymules, whereas the distal ones are unisexual (staminate) and apparently unifloral. In some specimens (e.g., Amorim et al. 8223) petiolar glands were observed only in a few leaves so it is possible that those glands are caducous.

Croton oliganthus is morphologically most similar to $C$. macrobothrys, mainly due to the leaf indument and fruit shape. However, both species can be distinguished by several features as shown in Table 4.

As the types of Croton oliganthus (Sellow s.n.) are incomplete specimens because they lack reproductive structures, we choose an epitype with reproductive structures to better represent the species.

Croton oliganthus is here tentatively included in Croton sect. Quadrilobi Müll.Arg. in virtue of its appressedstellate to stellate-lepidote trichomes, acropetiolar glands, leaf margin entire to sinuous, inflorescences terminal, low number of stamens (ca. 11), valvate pistillate flowers, and styles with 6 terminal tips (bifid).

Croton organensis Baill., Adansonia 4: 324. 1864.TYPE: Brazil, Rio de Janeiro: Serra dos Órgãos, May 1839, J.B.A. Guillemin cat. 938 (holotype: P 00634527!) (Fig. 10a-d).

Trees up to $15 \mathrm{~m}$ tall; latex clear; trichomes on young branches simple, stellate to dendritic; young branches strongly flattened. Leaves ovate-lanceolate to elliptic; adaxial surface sparsely pubescent, abaxial surface pubescent; margin irregularly serrate; glands 2, basilaminar, sessile, maculate and inconspicuous; stipules filiform. Inflorescences terminal, lax, axis flattened, proximal cymules bisexual. Staminate flowers subcampanulate, pedicellate, calyx lobes rhomboidal; stamens ca. 15. Pistillate flowers flask-shaped, pedicellate, calyx lobes imbricate, united at the base, rhomboidal; petals absent; styles multifid, with ca. 24 terminal tips, united at the base. Capsules ellipsoid, smooth; seeds subglobose, ribbed.

Phenology: Flowering from October to January, May and July; fruiting in November, December, February, May and July.

Habitats: Croton organensis is found in edges of wet forests.

Distribution: The species is endemic to the ARF and occurs in the Brazilian states of Minas Gerais, Rio de Janeiro and São Paulo, at 356-1660 m elevation.

Additional specimens studied: Brazil. Minas Gerais: Paraiso, 14 Oct 2000, G.S. França and J.R. Stehmann 140 (SP, BHCB). Rio de Janeiro: Resende, 13 Feb 2016, R.F. Santos et al. 52 (SP). São Paulo: Cunha, 30 Nov 2004, M.B.R. Caruzo et al. 82 (SP, SPF, WIS).

Conservation status: Croton organensis can be categorized as Least Concern (LC) because it is relatively widely distributed and very common in its area of
Table 4 Main morphological characters distinguishing Croton oliganthus, C. macrobothrys subsp. macrobothrys and C. macrobothrys subsp. septentrionalis

\begin{tabular}{llll}
\hline Characters & C. oliganthus & $\begin{array}{l}\text { C. macrobothrys subsp. } \\
\text { macrobothrys }\end{array}$ & $\begin{array}{l}\text { C. macrobothrys } \\
\text { subsp. septentri- } \\
\text { onalis }\end{array}$ \\
\hline Petiolar glands & Shortly stipitate & Stipitate & Sessile \\
Stipules & Subulate & Filiform & Filiform \\
Leaf shape & Oblong & Ovate-lanceolate & Ovate \\
Leaf margin & Crenate & Serrate & Entire \\
Petiole length & $<1 \mathrm{~cm}$ & $\geq 2 \mathrm{~cm}$ & $\geq 2 \mathrm{~cm}$ \\
Number of stamens & 11 & ca. 25 & ca. 25 \\
\hline
\end{tabular}


occurrence, besides having several populations in protected areas.

Notes: Croton organensis is the only arborescent Croton in ARF presenting maculate and inconspicuous laminar glands toward the base of the leaf (more visible in fresh material). Besides that, the species is easily recognized by the presence of strongly flattened branchlets, clear latex, leaves with parallel second veins, imbricate calyx lobes of pistillate flowers, with ferrugineous base and greenish apex, and styles united forming a long column.
Croton piptocalyx Müll.Arg., Fl. Bras. 11(2): 103. 1873.-TYPE: Brazil, Minas Gerais: Lagoa Santa, s.d., J.E.B. Warming 1636 (lectotype: C, designated by Caruzo and Cordeiro (2007: 582), second-step lectotype designated here: C 10011191!; isolectotypes: C 10011190!, G 00434645!); Rio de Janeiro: "prope Canta Gallo", s.d., T. Peckolt 4 (syntypes: BR 0000008760128!, BR 0000008760159!, BR 0000008760067!, BR 0000008760098!); “in Brasília meridionali prope S. Carlos", s.d., V. Helmreichen 40 (syntypes: W!, A 00257977!, F 0093320!); "inter Canna Verde et Casa branca”, s.d.,
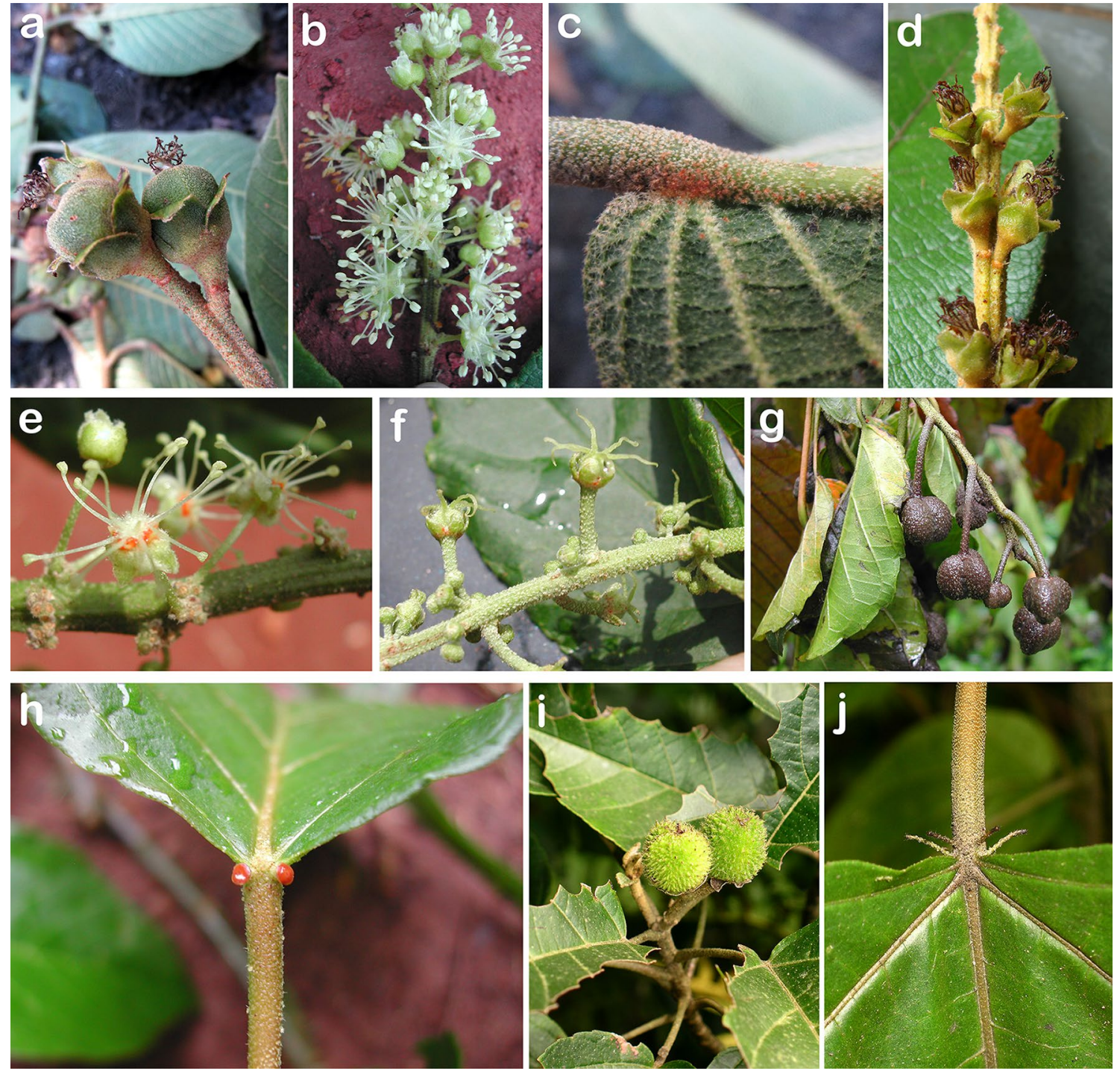

Fig. 10 Croton organensis a fruits, b detail of inflorescence with staminate flowers, $\mathbf{c}$ base of leaf apparently without glands, $\mathbf{d}$ detail of inflorescence showing pistillate flowers. Croton piptocalyx e staminate flowers with orange nectaries, $\mathbf{f}$ detail of inflorescence showing pistillate flowers with orange nectaries, $\mathbf{g}$ mature fruits, $\mathbf{h}$ petiolar glands. Croton priscus $\mathbf{i}$ fruits, $\mathbf{j}$ stipitate petiolar glands. $\mathbf{a}-\mathbf{h}$ by M.B.R. Caruzo; $\mathbf{i}, \mathbf{j}$ by R. Riina 
Regnell 1076 (syntypes S [n.v.], BR!); s.loc., s.d., J. Pohl s.n. (syntypes: W [n.v.], BR 0000008760005!, BR 0000008761019!, BR 0000008761040!, BR 0000008761071!, BR 0000008761101!, BR 0000008759948!, BR 0000008759979!) (Fig. 10e-h).

Vernacular names: Adrago, peloteira, curamadre, caxeta and caixeta.

Trees up to $24 \mathrm{~m}$ tall; latex clear; trichomes on young branches appressed-stellate, rarely dendritic. Leaves ovate; adaxial surface glabrescent to glabrate, abaxial surface sparsely pubescent; margin irregularly serrate; glands 2, acropetiolar, sessile to subsessile, patelliform; stipules linear-lanceolate, deciduous. Inflorescences terminal, lax, proximal cymules bisexual. Staminate flowers rotate, calyx with an evident midvein; stamens ca. 15. Pistillate flowers rotate, pedicellate, valvate, calyx lobes lanceolate; petals filiform, margin villose; styles with 6 terminal tips. Capsules obovate, smooth; seeds oblong, smooth.

Phenology: Flowering from October to December; fruiting from November to March.

Habitats: Croton piptocalyx is found at the edge of semideciduous and deciduous forests, at 650-1093 m elevation. Distribution: It occurs in southeastern Brazil (Minas Gerais, Rio de Janeiro and São Paulo).

Additional specimens studied: Brazil. Minas Gerais: Matão, 17 Nov 1984, P.M. Andrade and M.A. Lopes 470 (BHCB). São Paulo: Campinas, Nov 2004, M.B.R. Caruzo et al. 79 (SP, WIS). Rio de Janeiro: Paraíba do Sul, 26 Nov 1881, s. col., s.n. (R 10091, INPA).

Conservation status: Croton piptocalyx can be categorized as Least Concern (LC) because it is relatively broadly distributed and very common in its area of occurrence.

Notes: Croton piptocalyx can be easily recognized in the field by the strong orange coloration of its petiolar glands and nectary disk of both staminate and pistillate flowers (Caruzo 2005). Müller Argoviensis (1873) mentioned in the protologue of $C$. piptocalyx the presence of an additional splitting at the apex of styles (i.e., twice-bifid styles). However, this feature was rarely observed among the specimens analized.

Some collections of Croton piptocalyx have been erroneously identified as $C$. priscus, but the two species can be easily distinguished by several reproductive and floral characters (Table 5).

We selected a single herbarium sheet deposited at the University of Copenhagen herbarium (C) to designate the second-step lectotype for this name, for the same reasons given in the case of Croton gracilipes (see comments under C. gracilipes).

Croton priscus Croizat, Darwiniana 6: 454. 1944.TYPE: Brazil, São Paulo: Santo André, 5 Dec 1918, F.C. Hoehne s.n. (holotype: SP 2593!; isotypes: A 00277363!, A 00047385!, SPF 00064975!) (Fig. 10i-j).

Trees up to $10 \mathrm{~m}$ tall; latex clear; trichomes on young branches stellate, appressed-stellate and dendritic. Leaves obovate to widely elliptic; adaxial and abaxial surface glabrescent; margin crenate; glands $2-4$, acropetiolar, stipitate, patelliform; stipules linear-lanceolate. Inflorescences terminal, lax, proximal cymules bisexual. Staminate flowers subcampanulate, shortly pedicellate, calyx lobes rhomboidal; stamens ca. 20. Pistillate flowers campanulate, long pedicellate, reduplicate-valvate, calyx lobes rounded; petals filiform, inconspicuous; styles with 12 terminal tips, slightly united at the base. Capsules globose, muricate, covered with projections ending in a stellate trichome, pedicels and calyx accrescent; seeds elliptic to globose.

Phenology: Flowering from September to October; fruiting in September and from December to February.

Habitats: Croton priscus occurs in wet forests, at 780-950 m elevation.

Distribution: It is an endemic species from "Serra do Mar," in São Paulo state.

Additional specimens studied: Brazil. São Paulo: Santo André, 3 Sep 2004, M.B.R. Caruzo et al. 63 (SP).

Conservation status: Croton priscus can be categorized as Endangered (EN B2ab[iii]) because it has been collected in fewer than 5 locations and its geographic range is smaller than $500 \mathrm{~km}^{2}$.

Notes: Sterile specimens of Croton priscus and Alchornea glandulosa Poepp. could be confused because their leaves are morphologically similar and the two species occur in sympatry (Caruzo 2005). Another species similar to Croton priscus is C. piptocalyx, but they can be distinguished by several morphological features (Table 5).

Croton pseudopopulus Baill., Adansonia 4: 335. 1864.TYPE: Brazil, Rio de Janeiro, 1816/1821, A. Saint-Hilaire B1-18 (holotype: P 00634613!; isotypes A 00047388!, F 0056186!, P 00634612!).

Trees up to $10 \mathrm{~m}$ tall; latex not seen; trichomes on young branches stellate-porrect and dendritic. Leaves ovate 
Table 5 Main morphological characters distinguishing Croton pseudopopulus, C. piptocalyx and C. priscus

\begin{tabular}{llll}
\hline Characters & C. pseudopopulus & C. piptocalyx & C. priscus \\
\hline Petiolar glands & Stipitate & Sessile to subsessile & Stipitate \\
Leaf shape & Ovate to rounded & Ovate & Obovate to broadly elliptic \\
Sepals of staminate flower & Membranaceous, valvate & Foliaceous, valvate & Foliaceous, reduplicate-valvate \\
Sepals of pistillate flower & Elliptic to ovate & Lanceolate & Rounded \\
Stamens number & ca. 12 & ca. 20 & ca. 15 \\
Pedicel of pistillate flower & $2-5 \mathrm{~mm}$ & $5-10 \mathrm{~mm}$ & $5-7 \mathrm{~mm}$ \\
Styles & 6 terminal tips & 6 terminal tips & 12 terminal tips \\
Capsule surface & Unknown & Smooth & Muricate \\
Calyx in fruit & Unknown & Caducous & Persistent \\
\hline
\end{tabular}

to rounded; adaxial and abaxial surface glabrescent to sparsely pubescent; margin serrate to entire; glands 2-4, acropetiolar, stipitate, patelliform; stipules filiform. Inflorescences terminal, lax, proximal cymules bisexual. Staminate flowers rotate, calyx lobes ovate, membranaceous; stamens ca. 20. Pistillate flowers rotate, pedicellate, valvate, calyx lobes $5(-6)$, elliptical to ovate; petals filiform, sometimes deciduous; styles with 6 terminal tips, free. Fruits and seeds not seen.

Phenology: Found with flowers in November.

Habitats: Croton pseudopopulus is found in seasonally dry forests.

Distribution: The species is known only from its type material, from Rio de Janeiro, and a specimen recently collected in Uberlândia (Minas Gerais).

Additional specimens studied: Brazil. Minas Gerais: Uberlândia, 16 Feb 1994, A.L.P. Mota 2284 (SP, VIC).

Conservation status: Croton pseudopopulus can be categorized as Endangered (EN B1ab[iii]) because it has been collected in fewer than five locations and its geographic range is smaller than $5000 \mathrm{~km}^{2}$.

Notes: The collection from Mota 2284 was erroneously identified as Croton piptocalyx. These two species can be differentiated by number of stamens (ca. 12 in C. pseudopopulus vs. ca. 20 in $C$. piptocalyx) and by several reproductive features (Table 5).

Croton rottlerifolius Baill., Adansonia 4: 327. 1864.TYPE: Brazil, Minas Gerais: 1838, P. Claussen 788 (holotype: P 00634668!; isotypes: A 00257989!, G 00434624!) (Fig. 11a-e).

Trees up to $6 \mathrm{~m}$ tall; latex clear; trichomes on young branches stellate and appressed-stellate, stipitate-multiradiate and simple; indument with blackened trichomes on young branches. Leaves ovate; adaxial surface glabrescent, abaxial surface pubescent; margin entire to slightly serrate; glands 2, acropetiolar, sessile, patelliform; stipules linear. Inflorescences terminal, lax, sometimes apparently branched, cymules bisexual. Staminate flowers campanulate, shortly pedicellate, calyx united up to half; stamens ca. 15. Pistillate flowers campanulate, pedicellate, imbricate, sometimes with margin of calyx lobes with a different texture and color; petals absent; styles with 12 terminal tips, united at the base. Capsules subglobose, smooth, sometimes with blackened trichomes at the apex; seeds oblong, smooth.

Phenology: Flowering from September to March; fruiting from January to April and October to December.

Habitats: The species is found in seasonally dry forests, at 574-920 m elevation.

Distribution: Croton rottlerifolius occurs in Brazil, in the states of São Paulo, Minas Gerais, Mato Grosso do Sul and Bahia.

Additional specimens studied: Brazil. Bahia: Rui Barbosa, 20 Dec 2004, L.P. de Queiroz 10005 (SP, HUEFS). Minas Gerais: Pains, 8 Dec 2003, A.P. and G.P. Santos 984 (SP, BHCB). São Paulo: Águas da Prata, 13 Jan 2016, R.F. Santos et al. 41 (SP).

Conservation status: Croton rottlerifolius can be considered as Least Concern (LC) because this species has a wide extent of occurrence and can be found in numerous localities within its range of distribution.

Notes: Croton rottlerifolius can be recognized in the field by its young branches and capsules (apical portion) covered by blackened trichomes and the campanulate and shortly pedicellate staminate flowers.

Croton salutaris Casar., Nov. stirp. bras. 10: 89. 1845.TYPE: Brazil. Rio de Janeiro: "Serra dos Órgãos", s.d., G. 
Casaretto 856 (holotype: TO; isotype G-DC 00311745!) (Fig. 11f-k).

Vernacular names: Cambraia and sangue-de-drago.

Trees up to $15 \mathrm{~m}$ tall; latex reddish; trichomes on young branches lepidote; branchlets strongly angled. Leaves ovate, rarely cordate; adaxial surface sparsely lepidote, abaxial surface densely lepidote, silvery; margin entire; glands 2, acropetiolar, stipitate, patelliform; stipules elongated, linear-lanceolate. Inflorescences terminal, lax, proximal cymules bisexual. Staminate flowers campanulate, calyx lobes ovate, united up to half of their length; stamens ca. 15. Pistillate flowers flask-shaped, pedicellate, calyx lobes slightly united at the base, ovate; petals reduced to ovoid glands; styles with 12 terminal tips, united at the base. Capsules ellipsoid, smooth, apex with rufous trichomes; seeds ellipsoid, smooth.

Phenology: Flowering in January, March, April, July, August, November and December; fruiting from August to April.

Habitats: Croton salutaris is endemic from Altantic Rain forest, occurring in montane wet forest, at $700-950 \mathrm{~m}$ elevation.

Distribution: The species occurs in southern and southeastern Brazil (Minas Gerais, Espirito Santo, Paraná, Rio de Janeiro and São Paulo). Silva et al. (2010) mention the occurrence of Croton salutaris for the locality of Brejo da Madre de Deus, in Pernambuco state. However, the plants occurring in that region are actually $C$. hemiargyreus. Croton salutaris and $C$. hemiargyreus are morphologycally similar, but the two species differ from each other in several vegetative and floral features (see comments under $C$. hemiargyreus).

Additional specimens studied: Brazil. Minas Gerais: Juiz de Fora, 22 Jan 1993, M. Eiterer and D.S. de Almeida 26351 (ESA, CESJ). Espirito Santo: Alegre, $22 \mathrm{Feb}$ 2000, V.C. Souza et al. 23650 (ESA). Rio de Janeiro: Nova Friburgo, 31 Jan 2008, F.L.R. Filardi and J.E. Meireles 832 (RB, SP). São Paulo: Cunha, Nov 2004, M.B.R. Caruzo et al. 81 (SP, SPF, WIS).

Conservation status: Croton salutaris can be considerered as Least Concern (LC) because it is relatively widely distributed and very common in its area of occurrence, besides having populations in several protected areas in southeastern Brazil.

Notes: Croton salutaris differs from the other arborescent Croton in the ARF by its strongly angled branchlets, and flask-shaped pistillate flowers with rufous-silvery lepidote trichomes. Another species morphologically similar to Croton salutaris is Croton campanulatus, but they can be easily distinguished by differences in vegetative and floral characters (see comments in C. campanulatus). Croton salutaris is also similar to $C$. hemiargyreus in the lepidote indument and stipitate petiolar glands, but they differ in petiole morphology (strongly angled with crests in $C$. salutaris vs. cylindrical and smooth in $C$. hemiargyreus), leaf margin (entire in $C$. salutaris vs. serrate in $C$. hemiargyreus) and pistillate flowers (flask shaped in $C$. salutaris vs. campanulate in $C$. hemiargyreus).

Croton sapiifolius Müll.Arg., Linnaea 34: 137. 1865.TYPE: Brazil. s.d., F. Sellow 557 (lectotype: G-DC 00312879!, designated by Riina et al. (2010: 101); isolectotypes A 00047413!, B $\dagger$ [photo F 0BN005159!], G 00434698!).

Trees up to $10 \mathrm{~m}$ tall; latex not seen; trichomes on young branches appressed-stellate, stellate-porrect, stellatelepidote. Leaves elliptic to oblong; adaxial and abaxial surface sparsely pubescent to glabrescent; margin sinuous, with glands in the sinuses; glands $2-4$, acropetiolar, sessile, globose; stipules filiform to triangular. Staminate inflorescences axillary, lax. Pistillate inflorescences terminal, lax. Staminate flowers 4-merous, rotate; stamens 10-15. Pistillate flowers campanulate, pedicellate, valvate, calyx lobes triangular; petals filiform, usually deciduous; styles with 6-8 terminal tips, free or slightly united at the base; ovary 2(-3) locular. Capsules obovate to oblong, 2(-3) locular; seeds obovoid, smooth, sometimes maculate.

Phenology: Flowering from August to September and December to January; fruiting in May, July, August, and December.

Habitats: According to Riina et al. (2010), Croton sapiifolius was known to occur only in wet and seasonally forest of southern Bahia. However, recently, a specimen of this species was found in "restingas" forests of Espirito Santo state (Santos et al. 2016).

Distribution: Croton sapiifolius is endemic species from the ARF, occurring at 100-200 m elevation.

Additional specimens studied: Brazil. Espirito Santo: Vitória, 28 Nov 1997, A.M. Assis and I. Weiler Júnior 298 (SP, VIES). Bahia: Uruçuca, 01-12 Jul 1991, A.M de Carvalho et al. 3400 (SP, CEPEC).

Conservation status: Croton sapiifolius can be considerered as Vulnerable (VU B2ab[iii]) because it has been collected in less than 10 locations and its geographic range is inferior to $2000 \mathrm{~km}^{2}$.

Notes: Croton sapiifolius can be easily recognized by its coriaceous leaves with sinuous margin, sessile 

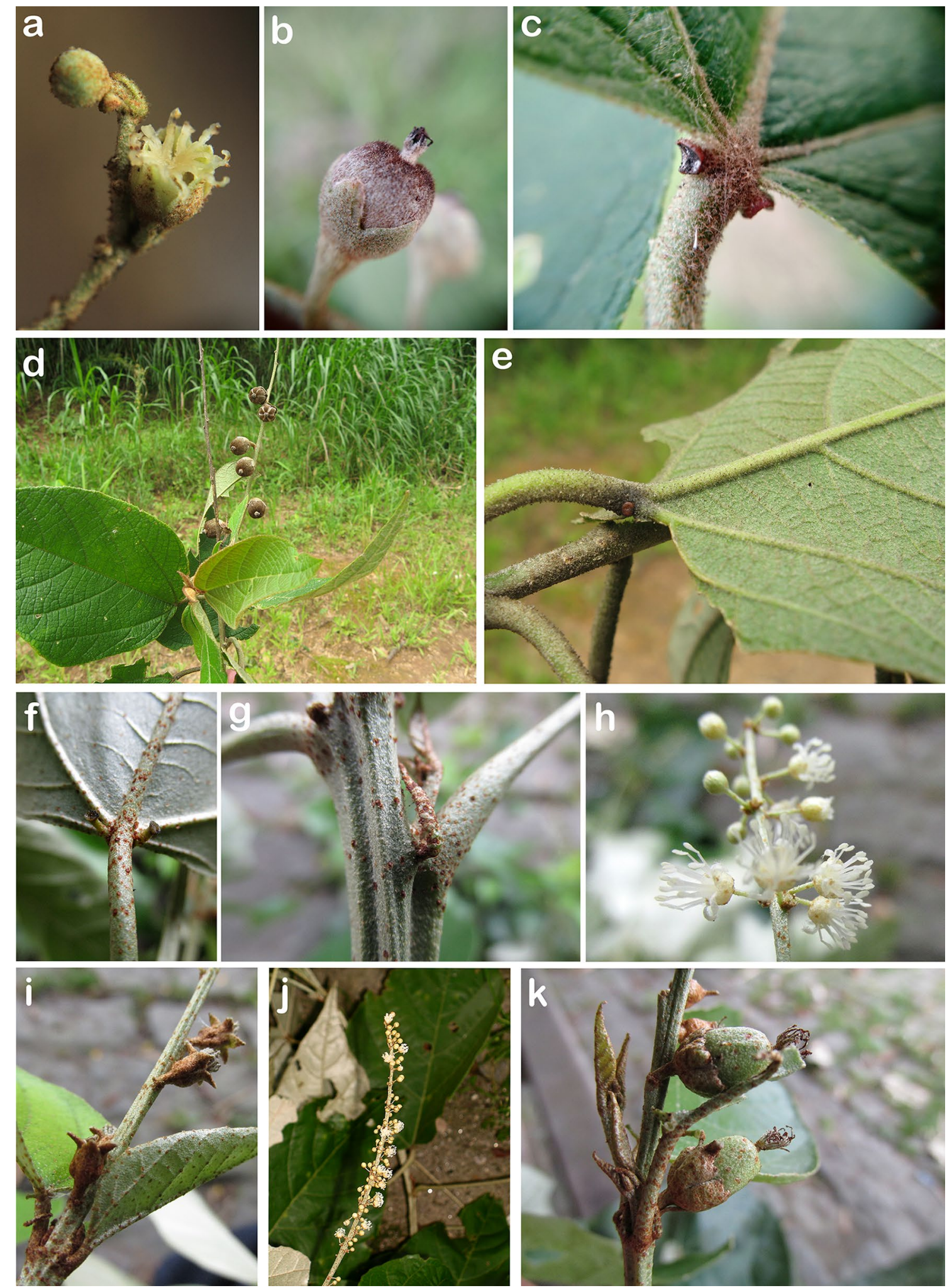
4Fig. 11 Croton rottlerifolius a pistillate flower showing styles, $\mathbf{b}$ fruit with blackened indument at the apex, $\mathbf{c}$ petiolar glands, $\mathbf{d}$ branchlet with fruits, e detail of petiole showing blackened indument at the apex. Croton salutaris $\mathbf{f}$ petiolar glands, $\mathbf{g}$ detail of angled branchlet showing stipules, $\mathbf{h}$ staminate flowers, $\mathbf{i}$ detail of inflorescence showing pistillate flowers, $\mathbf{j}$ inflorescence showing staminate flowers, $\mathbf{k}$ immature fruits, $\mathbf{a}-\mathbf{c}$ by O.L.M. Silva; $\mathbf{d}$, e by M.B.R. Caruzo; $\mathbf{f}-\mathbf{i}, \mathbf{k}$ by R.F.Santos

acropetiolar glands, unisexual inflorescences (with staminate inflorescences axillary and pistillate terminal), staminate flowers 4-merous, shortly pedicellate and with 10-15 stamens, pistillate flowers valvate and pedicellate, usually 2-locular ovary.

The specimens of Croton sapiifolius found in the Espirito Santo herbarium (VIES) was erroneously identified as $C$. polyandrus Spreng. These species can be easily distinguished by their habit (arborescent in $C$. sapiifolius vs. shrubby in $C$. polyandrus), leaf margin (sinuous in $C$. sapiifolius vs. crenate in $C$. polyandrus), number of carpels (usually 2 in $C$. sapiifolius vs. always 3 in $C$. polyandrus) and inflorescence sexuality (unisexual in C. sapiifolius vs. bisexual in C. polyandrus).

Croton thomasii Riina \& P.E.Berry, Candollea 65: 101. 2010: 101.-TYPE: Brazil, Bahia: Ilhéus, 15 Jan 1995, W.W. Thomas et al. 10793 (holotype: CEPEC 65669!; isotypes G 00434664!, MBM [n.v.], MO 2215107!, NY 00504337!, SP).

Vernacular names: Tapioca, embira.

Trees up to $18 \mathrm{~m}$ tall; latex reddish; trichomes on young branches stellate-rosulate. Leaves ovate to elliptic; adaxial and abaxial surface glabrescent; margin crenate, slightly revolute; glands 2, acropetiolar, sessile, globose; stipules filiform, deciduous. Inflorescences terminal, congested, proximal cymules bisexual. Staminate flowers rotate; stamens ca. 15. Pistillate flowers campanulate, pedicellate, reduplicate-valvate, calyx lobes oblongovate; petals absent; styles with 12 terminal tips, free from the base. Capsules globose, smooth; seeds oblong, smooth.

Phenology: Flowering in November and January; fruiting in February.

Habitats: The species occurs in wet forest, at $100-150 \mathrm{~m}$ elevation.

Distribution: Croton thomasii occurs in southern Bahia, Brazil.

Additional specimens studied: Brazil. Bahia: Una, 12 Nov 1971, D.P. Lima 12734 (RB, HST).
Conservation status: Croton thomasii can be considerered Endangered (EN B2ab[iii]) because it has been collected in fewer than 5 locations and its geographic range is smaller than $500 \mathrm{~km}^{2}$.

Notes: According to Riina et al. (2010), most specimens of Croton thomasii were previously identified as C. piptoca$l y x$, possibly due to the similarity of these species in habit and leaf morphology. However, they can be distinguished by their latex color (reddish in $C$. thomasii vs. clear in $C$. piptocalyx), type of trichomes (stellate-rosulate in $C$. thomasii vs. appressed-stellate in C. piptocalyx), pistillate flowers (campanulate and reduplicate-valvate in $C$. thomasii vs. rotate and valvate in $C$. piptocalyx), number of styles division (tetrafid, with 12 terminal tips in $C$. thomasii vs. bifid, with 6 terminal tips in C. piptocalyx) and fruit morphology (globose in $C$. thomasii vs. obovate $C$. piptocalyx).

Croton urucurana Baill., Adansonia 4: 335. 1864.TYPE: Brazil. s.d., Saint-Hilaire s.n. (lectotype: P, designated by Smith et al. (1988), second-step lectotype designated here: P 00634744!; isolectotype P 00634745!). Minas Gerais: s.d., Claussen 770 (syntypes: P 00634746!, P 00634747!, SP 000667!, G-DC 00311423!), s.loc., s.d., Pissis 9 (syntypes: $\mathrm{P} 00634749$ !, $\mathrm{P}$ 00634748!, SP 000668!) (Fig. 12a-e).

Vernacular names: Adrago, licurana, sangue de drago, sangra d'agua and urucurana.

Trees up to $10 \mathrm{~m}$ tall; latex reddish; trichomes on young branches dendritic, stellate-porrect and appressed-stellate. Leaves cordate to ovate-lanceolate; adaxial surface sparsely pubescent, abaxial surface densely pubescent; margin entire, with colleters (minute ovoid glands); glands 2(4), acropetiolar, sessile, globose; stipules foliaceous usually with a broad base and a narrow to filiform apex. Inflorescences terminal, lax, proximal cymules bisexual. Staminate flowers rotate; stamens 15-20. Pistillate flowers rotate, pedicellate, valvate, calyx lobes ovate; petals filiform; styles with 6 terminal tips, free from the base. Capsules subglobose, smooth; seeds globose, striated.

Phenology: Flowering and fruiting throughout the year.

Habitats: The species is found at the edges of seasonally dry forests and riparian forests, at 300-1300 m elevation.

Distribution: Croton urucurana is widely distributed in southern South America. It occurs in Argentina (Missiones), Paraguay (Amambay) and Brazil (Acre, Amazonas, Bahia, Distrito Federal, Espirito Santo, Goiás, Maranhão, Mato Grosso, Mato Grosso do Sul, Minas Gerais, 

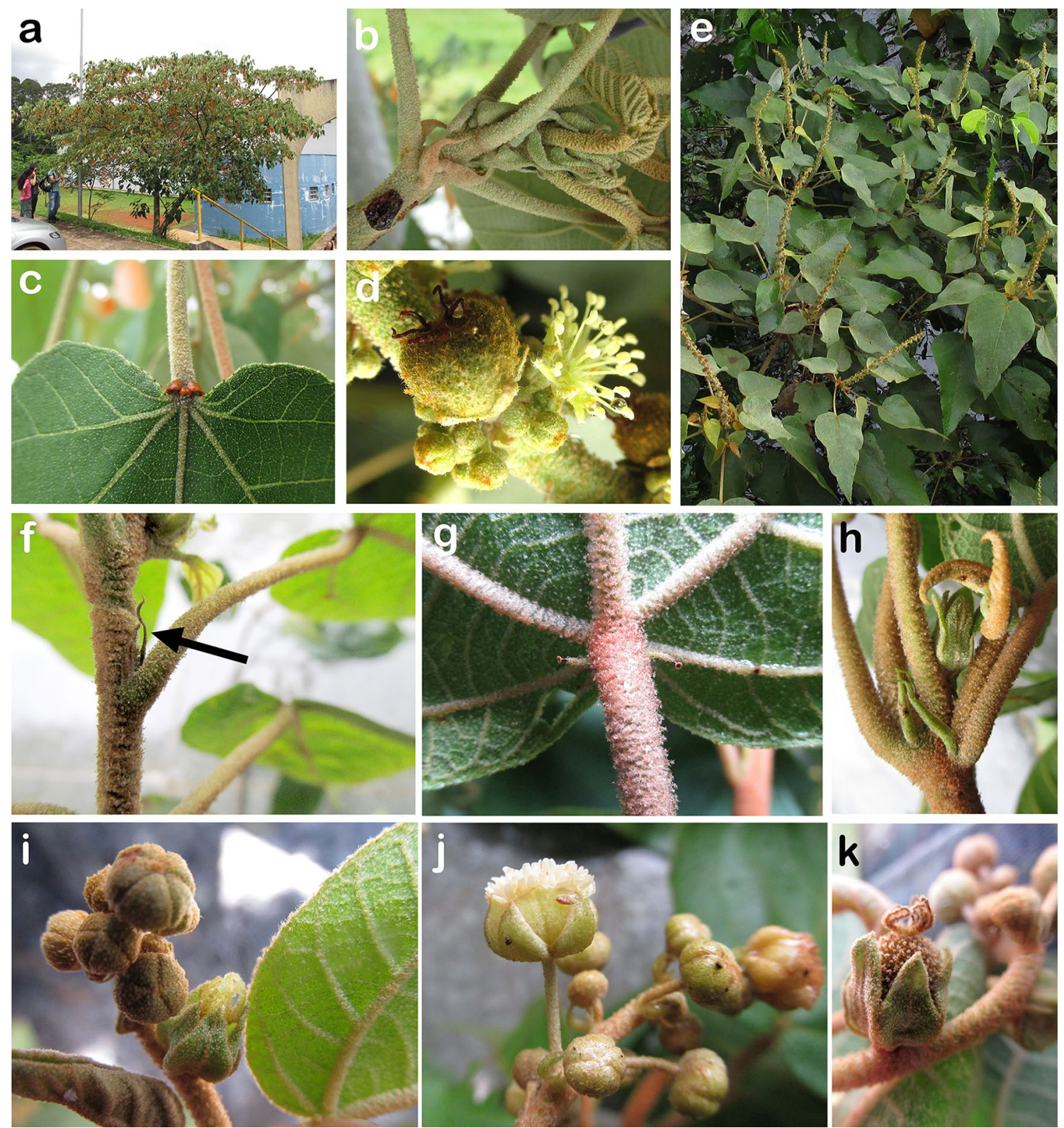

Fig. 12 Croton urucurana a habit, $\mathbf{b}$ detail of branchlet showing stipules, $\mathbf{c}$ petiolar glands, $\mathbf{d}$ detail of a cymule showing a fruit, a staminate flower and several flower buds, e branches showing erect inflorescences. Croton vulnerarius $\mathbf{f}$ detail of branchlet showing stipules,

Rio de Janeiro, São Paulo, Pará, Paraná, Santa Catarina, Rio Grande do Sul, Rondônia and Tocantins).

Additional specimens studied: Argentina. Corrientes: Departamento Santo André, 19 Jan 2000, M.M. Arbo et al. 8582 (ALCB, CTES). Missiones: Departamento Leandro N. Além, 4 Feb 1999, V. Marufiak 962 (ALCB, IAC, CTES, HUEFS). Brazil. Acre: Brasiléia, Mar 1998, D. Daly et al. 9721 (MG). Amazonas: Humaitá, s.d., J.G. Kuhlmann 316 (RB). Bahia: Alcobaça, 28 Jan 2015, R.F. Santos et al. g petiolar glands, $\mathbf{h}$ branchlet detail showing stipules and young pistillate flower, $\mathbf{i}$ young inflorescence with pistillate flower at the base and distal staminate flower buds, $\mathbf{j}$ detail of staminate flower, $\mathbf{k}$ young fruit. $\mathbf{a}-\mathbf{c}, \mathbf{f}-\mathbf{k}$ by R.F. Santos; $\mathbf{d}$, e by O.L.M. Silva

21 (SP). Distrito Federal, Núcleo Bandeirantes, 28 Jun 1984, E.P. Heringer s.n. (CEPEC 34550, IBGE). Espirito Santo: Linhares, 4 Mar 2004, P. Fiaschi et al. 2002 (RB, CEPEC). Goiás: Alto Paraiso, 2 Jun 1965, F.R. Rosa 16 (RB). Maranhão: Vianna, Jul 1992, O. Carvalho 71 (SP). Mato Grosso: Cuiabá, 15 Nov 1940, A.G. Nave et al. 1167 (UEC). Mato Grosso do Sul, Dourados, 12 Dec 1982, G. Hatschbach 45936 (MBM). Minas Gerais: Araxá, 8 Nov 2013, V. Conde s.n. (RB 532689). Rio de Janeiro: Resende, 
12 Feb 2016, R.F. Santos et al. 49 (SP). Rio Grande do Sul: Tenete Portela, Apr 1983, M. Sobral 1983 (SP). São Paulo: Jundiai, 2 Dec 2014, R.F. Santos et al. 5 (SP). Santa Catarina: Itaratinga, s.d., B. Rambo s.n. (PACA 1730). Tocantins: Brejinho de Nazaré, 24 Jan 2001, S.F. Lolis 1202 (HUEFS, UB). Paraguay. Amambay: s.loc.,17 Dec 1999, M.S. Ferrucci et al. 1619 (SP, HUEFS).

Conservation status: Croton urucurana can be considered as Least Concern (LC) because it is a widespread species that can be found in numerous locations within its range of distribution.

Notes: Croton urucurana is a pioneer species, very common in riparian forests (Smith et al. 1988). It can be confused with Croton gracilipes, mainly by its sessile acropetiolar glands and cordate leaves. However, they can be differentiated from each other in several features (see comments under $C$. gracilipes). Another species usually confused with Croton urucurana is C. celtidifolius, but they can be distinguished in several vegetative and floral characters (see comments under $C$. celtidifolius).

We designated here a single herbarium sheet as the second-step lectotype of $C$. urucurana (see comments under C. celtidifolius).

Croton vulnerarius Baill., Adansonia 4: 328. 1864.TYPE: Brazil, São Paulo, s.d., A. Saint-Hilare cat. C2 1405 (lectotype P, designated by Caruzo and Cordeiro (2007), second-step lectotype designated here: P 00634572!; isolectotype: P 00634569!); Mogi das Cruzes, s.d., SaintHilare cat. D 652 (syntypes: P 00634574!, P 00634573!) (Fig. 12f-k).

= Croton hecatonandrus Müll.Arg., Fl. Bras. 11(2): 705 . 1873.-TYPE: Brazil, Rio de Janeiro: Itatiaia, 07 Jun 1871, A. Glaziou 4916 (lectotype designated here: P 00623567!; isolectotypes $\mathrm{K} 000186061$ !, P 00623568!); Itatiaia, $11 \mathrm{Jul}$ 1872, A. Glaziou 5983 (syntype: B $\dagger$ [photo F-negative!]), syn. nov.

= Croton novi-friburgi Müll.Arg., Fl. Bras. 11(2): 97. 1873.-TYPE: Brazil, Rio de janeiro: Serra de Nova Friburgo, 22 May 1868, A. Glaziou 2690 (holotype: P 00634561!; isotypes: G 00434717!, A 00257967!, K 000186062!, C 10011201!), syn. nov.

Vernacular names: Sangue-de-boi.

Trees up to $8 \mathrm{~m}$ tall; latex reddish; trichomes on young branches appressed-stellate and dendritic, branches with floccose indument. Leaves cordate; adaxial surface pubescent to sparsely pubescent, abaxial surface densely pubescent; margin irregularly serrate; glands 2(4), acropetiolar, stipitate, patelliform; stipules elongated, lanceolate to filiform. Inflorescences terminal, lax, proximal cymules bisexual. Staminate flowers subcampanulate, long pedicellate to pedicellate; stamens $80-130$. Pistillate flowers campanulate, sessile to subsessile, valvate to slightly imbricate, calyx lobes ovate-lanceolate; petals linear-lanceolate; styles with 12 terminal tips, united at the base. Capsules globose, smooth; seeds subglobose, verrucose.

Phenology: Flowering from January to July and September; fruiting in September, October, February and April.

Habitats: Croton vulnerarius is endemic from the ARF and it occurs in wet and seasonally dry forests, at 780-1300 m elevation.

Distribution: It is distributed in the Brazilian states of Minas Gerais, Paraná, Rio de Janeiro and São Paulo.

Additional specimens studied: Brazil. Minas Gerais: Paraná: Jaguariaíva, 28 Mar 1974, R. Kummrow 468 (MBM, BHCB). Rio de Janeiro: Itatiaia: 12 Feb 2016, R.F. Santos et al. 47 (SP). São Paulo: São Paulo, 17 Feb 2016, R.F. Santos et al. 56 (SP).

Conservation status: Croton vulnerarius can be considered as Least Concern (LC) because it is relatively widely distributed and common in its area of occurrence, besides having populations in several protected areas of southeastern Brazil.

Notes: Croton novi-friburgi and C. hecatonandrus are here synonymized under $C$. vulnerarius after the analysis of specimens and protologues revealed that the characteristics used to differentiate them largely overlap and are not sufficient to treat them as distinct taxa.

Croton vulnerarius is most morphologically similar to $C$. lagoensis Müll.Arg., a shrubby species from seasonally dry forests of transitional areas between the ARF and Cerrado domains in Minas Gerais state. However, both species can be distinguished by the habit (arborescent in $C$. vulnerarius vs. shrubby in $C$. lagoensis), glands (stipitate and thiny in C. vulnerarius vs. sessile and robust in $C$. lagoensis), calyx lobes format (lanceolate to ovate-lanceolate in $C$. vulnerarius vs. ovate in C. lagoensis) and number of stamens (80-130 in C. vulnerarius vs. 40-50 in C. lagoensis). Another species morphologically similar to $C$. vulnerarius is $C$. celtidifolius, mainly by their stipitate acropetiolar glands and globose fruits, but they differ from each other in several features (Table 2).

We designated a single herbarium sheet as a second-step lectotype for this name (see comments under $C$. gracilipes).

\section{Conclusions}

According to our herbarium revision and field observations, Crotoneae trees appear to be fairly common and 
abundant in many areas throughout the ARF. Of the 23 tree species we recognize (two species of Brasiliocroton and 21 of Croton), about $70 \%$ are endemic to the ARF domain, three species are endangered, and a group of nine species are considered vulnerable. This study provides updated information on taxonomy and species ranges that will be useful for future studies and decision-making related to the conservation of the plant diversity of this highly threatened neotropical region.

\begin{abstract}
Acknowledgements This work is part of the Master thesis of RF Santos. We thank Amanda da Paixão Noranha Pereira, Daniela Carneiro-Torres and Otavio Luis Marques da Silva for providing photos of plants in the field. We are also grateful to all the herbaria cited for giving us access to their collections. Two anonymous reviewers made useful suggestions and corrections to improve an earlier version of this paper. Financial support was provided to MBR Caruzo (process 441049/2014-1) by "Conselho Nacional de Desenvolvimento Científico e Tecnológico" (CNPq).
\end{abstract}

\section{Compliance with ethical standards}

Conflict of interest The authors declare that they have no conflict of interest.

\section{Electronic supplementary material}

Online Resource 1. List of the studied taxa with their taxonomic authorities, and all the herbarium specimens examined (main collector, collection number and specimen determination).

\section{References}

Arévalo R, van Ee BW, Riina R, Berry PE, Wiedenhoeft AC (2017) Force of habit: shrubs, trees, and contingent evolution of wood anatomical diversity using Croton (Euphorbiaceae) as a model system. Ann Bot (Oxford) 119:563-579

Baillon H (1864) Euphorbiaceés Americaines. Adansonia 4:257-377

Berry PE, Hipp AL, Wurdack KJ, van Ee B, Riina R (2005a) Molecular phylogenetics of the giant genus Croton and tribe Crotoneae (Euphorbiaceae sensu stricto) using ITS and trnL-trnF DNA sequence data. Amer J Bot 92:1520-1534

Berry PE, Cordeiro I, Wiedenhoeft AC, Vitorino-Cruz MA, Lima LR (2005b) Brasiliocroton, a new crotonoid genus of Euphorbiaceae s.s. from eastern Brazil. Syst Bot 30:357-365

BFG - The Brazil Flora Group (2015) Growing knowledge: an overview of seed plant diversity in Brazil. Rodriguésia 66:1085-1113

Carneiro-Torres DS, Cordeiro I, Giulietti AM, Berry PE, Riina R (2011) Three new species of Croton (Euphorbiaceae s.s.) from the Brazilian Caatinga. Brittonia 63:122-132

Caruzo MBR (2005) Estudo Taxonômico e Biogeográfico do Gênero Croton L. (Euphorbiaceae) no Estado de São Paulo, Brasil. Universidade de São Paulo, São Paulo

Caruzo MBR, Cordeiro I (2007) Sinopse da tribo Crotoneae Dumort. (Euphorbiaceae s.s.) no Estado de São Paulo, Brasil. Hoehnea 34:571-585

Caruzo MBR, Cordeiro I (2013) Taxonomic revision of Croton section Cleodora (Euphorbiaceae). Phytotaxa 121:1-41

Caruzo MBR, Santos RF (2015) First record of Croton echinocarpus (Euphorbiaceae: Crotoneae) in São Paulo state, Brazil. Check List 11:1684
Caruzo MBR, Riina R, Cordeiro I, Berry PE (2008) Croton campanulatus (Euphorbiaceae s.s.), a new species from the Brazilian Atlantic rain forest. Brittonia 60:261-264

Caruzo MBR, Cordeiro I, Berry PE, Riina R (2010) A new species of Croton section Cleodora (Euphorbiaceae s.s.) from Minas Gerais, Brazil. Phytotaxa 3:27-33

Caruzo MBR, Silva OLM, Berry PE, Cordeiro I (2014) Nomenclatural novelties in Astraea (Euphorbiaceae). Phytotaxa 159:127-128

Caruzo MBR, Santos RFS, Feio AC, Meira RMSM, Riina R (2016) Redefinition of Croton macrobothrys (Euphorbiaceae), a tree species from the Brazilian Atlantic Forest, with the description of a new subspecies. Phytotaxa 273:51-58

Cordeiro I, Berry PE, Caruzo MBR, van Ee B (2008) Croton laceratoglandulosus (Euphorbiaceae s.s.), a new glandular-stipulate species from Brazil and Bolivia, and its systematic position based on molecular analysis. Bot J Linn Soc 158:493-498

Crepaldi CG, Campos JLA, Albuquerque UP, Sales MF (2016) Richness and ethnobotany of the family Euphorbiaceae in a tropical semiarid landscape of Northeastern Brazil. S African J Bot 102:157-165

Croizat L (1944) Additions to the genus Croton L. in South America. Darwiniana 6:442-468

Feio AC, Riina R, Meira RMSA (2016) Secretory structures in leaves and flowers of two Dragon's blood Croton (Euphorbiaceae): new evidence and interpretations. Int J P1 Sci 177:511-522

Flora do Brasil 2020 (in construction). Jardim Botânico do Rio de Janeiro. Available at http://floradobrasil.jbrj.gov.br/. Accessed 02 Jan 2017

Font Quer P (1977) Diccionario de botánica. Lábor, Barcelona

Frodin DG (2004) History and concepts of big plant genera. Taxon 53:753-776

Govaerts R, Frodin DG, Radcliffe-Smith A (2000) World checklist and bibliography of Euphorbiaceae (and Pandaceae), 2. Royal Botanic Gardens, Kew

Hickey LJ (1973) Classification of the architecture of dicotiledonous leaf. Amer J Bot 60:17-33

IUCN (2012) The IUCN red list categories and criteria: version 3.1, 2nd edn. IUCN, Gland, Cambridge

Lima LR, Pirani JR (2008) Three new species of Croton (Euphorbiaceae) from Brazil. Kew Bull 63:121-129

Medeiros D, Valle LDS, Esser HJ, Alves RJV (2016) Floristic and taxonomic treatment of Croton subsect. Medea (Euphorbiaceae) from Brazilian campos rupestres. Phytotaxa 263:167-201

Müller Argoviensis J (1873) Euphorbiaceae. In: Martius CFP, Eichler AW (eds) Flora Brasiliensis. Munich, vol. 11(2):1-752

Oliveira-Filho AT, Fontes MAL (2000) Patterns of floristic differentiation among Atlantic forest in southeastern Brazil and the influence of climate. Biotropica 32:793-810

Olson DM, Dinerstein E, Wikramanayake ED, Burgess ND, Powell GVN, Underwood EC, D'Amico JA, Itoua I, Strand HE, Morrison JC, Loucks CJ, Allnutt TF, Ricketts TH, Kura Y, Lamoreux JF, Wettengel WW, Hedao P, Kassem KR (2001) Terrestrial ecoregions of the world: a new map of life on Earth. Bioscience 51(11):933-938

Radcliffe-Smith A, Govaerts R (1997) New names and combinations in the Crotonoideae. Kew Bull 52:183-189

Radford AE, Dickison WC, Massey JR, Bell CR (1974) Vascular plant systematics. Harper and Row Publishers, New York

Riina R, Cordeiro I, Amorim AM, Berry PE (2010) Croton thomasii Riina \& P. E. Berry (Euphorbiaceae), a new species from the Atlantic Forest in the State of Bahia (Brazil) and typification of Croton sapiifolius Müll.Arg. Candollea 65:101-107

Riina R, Carneiro-Torres D, Peirson JA, Berry PE, Cordeiro I (2014) Further support for the Crotoneae phylogeny: a new species of 
Brasiliocroton (Euphorbiaceae) based on morphological, geographical, and molecular evidence. Syst Bot 39:227-234

Salatino A, Salatino MLF, Negri G (2007) Traditional uses, chemistry and pharmacology of Croton species (Euphorbiaceae). J Braz Chem Soc 18:11-33

Santos RF, Caruzo MBR (2015) Sinopse da tribo Alchorneae (Euphorbiaceae) no Estado de São Paulo, Brasil. Hoehnea 42:165-170

Santos RF, Riina R, Caruzo MBR (2016) Croton sapiifolius Müll. Arg: a new occurrence for the State of Espírito Santo, Brazil. Hoehnea 43:529-531

Secco R (2009) Uma nova espécie de Croton sect. Geiseleria (Euphorbiaceae) da Amazônia Oriental brasileira. Revista Brasil Bot 32:249-252

Secco R, Berry PE (2010) Croton borbensis, a new species of Euphorbiaceae from white sands of Amazonian Brazil. Brittonia 62:116-119

Secco RS, Cordeiro I, Senna-Vale L, Sales MF, Lima LR, Medeiros D, Sá-Haiad B, Oliveira AS, Caruzo MBR, Carneiro-Torres D, Bigio NC (2012a) An overview of recent taxonomic studies on Euphorbiaceae s.l. in Brazil. Rodriguésia 63:227-242

Secco R, Do Rosario AS, Berry PE (2012b) Croton campinarensis (Euphorbiaceae), a new species from eastern Amazonian Brazil. Phytotaxa 49:1-5

Silva SA, Sales MF, Gomes APS, Carneiro-Torres DS (2010) Sinopse das espécies de Croton L. (Euphorbiaceae) no estado de Pernambuco, Brasil. Acta Bot Brasil 24:441-453

Silva OLM, Cordeiro I, Caruzo MBR (2014a) Synopsis of Euphorbia (Euphorbiaceae) in the state of São Paulo, Brazil. Phytotaxa 181:193-215

Silva MJD, Sodré RC, Sales MFD (2014b) A new species of Croton L. (Euphorbiaceae ss) from the Brazilian Cerrado. Syst Bot 39:216-221
Smith LB, Downs RJ, Klein RM (1988) Euforbiáceas. In: Reitz R (ed) Flora ilustrada catarinense, pp 1-137

Stehmann JR, Forzza RC, Sobral M, Kamino LHY (2009) Gimnospermas e angiospermas. In: Stehmann JR, Forzza RC, Salino A, Sobral M, Costa DP, Kamino LHY (eds) Plantas da floresta Atlântica. Jardim Botânico do Rio de Janeiro, Rio de Janeiro

Thiers B (2016) Index Herbariorum, a global directory of public herbaria and associated staff. New York Botanical Garden's Virtual Herbarium. Available at: http://sweetgum.nybg.org/ih/. Accessed 15 Mar 2016

van Ee BW, Riina R, Berry PE (2011) A revised infrageneric classification and molecular phylogeny of New World Croton (Euphorbiaceae). Taxon 60:791-823

Viana PL, Mota NFDO, Gil ADSB, Salino A, Zappi DC, Harley RM, Ilkiu-Borges AL, Secco RS, Almeida TE, Watanabe MTC, Santos JUMD, Trovó M, Maurity C, Giulietti AM (2016) Flora of the cangas of the Serra dos Carajás, Pará, Brazil: history, study area and methodology. Rodriguésia 67(5SPE):1107-1124

Vitarelli NC, Riina R, Caruzo MBR, Cordeiro I, Fuertes-Aguilar J, Meira RMSA (2015) Foliar secretory structures in Crotoneae (Euphorbiaceae): diversity, anatomy, and evolutionary significance. Amer J Bot 102:833-847

Vitarelli NC, Riina R, Cassino MF, Meira RMSA (2016) Trichomelike emergences in Croton of Brazilian highland rock outcrops: evidences for atmospheric water uptake. Perspect Pl Ecol Evol Syst 22:23-35

Webster GL, Del-Arco-Aguilar MJ, Smith BA (1996) Systematic distribution of foliar trichome types in Croton (Euphorbiaceae). Bot J Linn Soc 121:41-57

Wurdack KJ, Hoffmann P, Chase MW (2005) Molecular phylogenetic analysis of uniovulate Euphorbiaceae (Euphorbiaceae sensu stricto) using plastid rbcL and trhL-F sequences. Amer J Bot 92:1397-1420 